\title{
Is global dimming and brightening in Japan limited to urban areas?
}

\author{
Katsumasa Tanaka ${ }^{1,2}$, Atsumu Ohmura ${ }^{2}$, Doris Folini ${ }^{2}$, Martin Wild $^{2}$, and Nozomu Ohkawara ${ }^{3}$ \\ ${ }^{1}$ Center for Global Environmental Research, National Institute for Environmental Studies (NIES), Tsukuba, Japan \\ ${ }^{2}$ Institute for Atmospheric and Climate Science, Swiss Federal Institute of Technology (ETH), Zurich, Switzerland \\ ${ }^{3}$ Global Environment and Marine Department, Japan Meteorological Agency (JMA), Tokyo, Japan
}

Correspondence to: Katsumasa Tanaka (tanaka.katsumasa@nies.go.jp)

Received: 1 July 2016 - Published in Atmos. Chem. Phys. Discuss.: 4 August 2016

Revised: 17 October 2016 - Accepted: 24 October 2016 - Published: 11 November 2016

\begin{abstract}
Worldwide observations indicate secular trends of all-sky surface solar radiation on a decadal time scale, termed global dimming and brightening. Accordingly, the observed surface radiation in Japan generally shows a strong decline until the end of the 1980s and then a recovery until around 2000. Because a substantial number of measurement stations are located within or close to populated areas, one may speculate that the observed trends are strongly influenced by local air pollution and are thus not of large-scale significance. This hypothesis poses a serious question as to what regional extent the global dimming and brightening are significant: are the global dimming and brightening truly global phenomena, or regional, or even only local? Our study focused on 14 meteorological observatories that measured all-sky surface solar radiation, zenith transmittance, and maximum transmittance. On the basis of municipality population time series, historical land use maps, recent satellite images, and actual site visits, we concluded that eight stations have been significantly influenced by urbanization, with the remaining six stations being left pristine. Between the urban and rural areas, no marked differences were identified in the temporal trends of the aforementioned meteorological parameters. Our findings suggest that global dimming and brightening in Japan occurred on a large scale, independently of urbanization.
\end{abstract}

\section{Introduction}

For centuries efforts have been put into place around the world to understand the surface energy budget of the earth (Ohmura, 2014). One of the pillars of such activities to date is the Global Energy Balance Archive (GEBA) project (Ohmura and Lang, 1989), which established a database for the measurements of surface solar radiation (SSR) and other parameters around the world (http://www.geba.ethz. ch). A major finding from the GEBA project was the global dimming and brightening phenomenon (Ohmura and Lang, 1989; Stanhill and Cohen, 2001; Wild et al., 2005), which referred originally to the secular trend of all-sky SSR on the decadal time scale in Europe that had declined until about the 1980 s and has been rising ever since (note that "global" refers to the sum of the direct and diffuse radiation rather than the geographical coverage). Secular trends under all-sky conditions have also been found elsewhere in the world, but the strength and the direction of the trend differ across regions (Wild et al., 2005; Ohmura, 2009; Wild, 2012).

It has been debated whether global dimming and brightening is caused by aerosols and/or cloud effects (Stanhill and Cohen, 2001; Wild, 2009). Although such effects are not entirely independent nor mutually exclusive because of aerosol-cloud interactions (i.e., aerosol indirect effects), we discuss these two factors separately below. Water vapor also influences the all-sky SSR; however, the magnitude of its impact is substantially smaller than that of aerosols (Kvalevåg and Myhre, 2007; Ohmura, 2009; Wild, 2009). In earlier studies, Ohmura and Lang (1989) proposed cloud changes as the cause of global dimming, while a few studies (Stanhill and Moreshet, 1992; Liepert et al., 1994) attributed the radiation changes to aerosols. Previous studies until now generally pointed to the dominant role of aerosols in bringing about global dimming and brightening in China and Japan (Kaiser and Qian, 2002; Hayasaka et al., 2006; Qian et al., 2006; Norris and Wild, 2009; Kudo et al., 2012; Wang et al., 2012; Wang and Yang, 2014), in Europe (Norris and Wild, 2007; Ruckstuhl et al., 2008; Wang et al., 2012), and globally (Wild et al., 2005) based on a variety of approaches to 
estimating or inferring clear-sky (or cloud-free) SSR. Streets et al. (2006) showed that the temporal trends of global mean aerosol optical depth (AOD) derived from emission inventories for sulfate dioxide $\left(\mathrm{SO}_{2}\right)$ and black carbon $(\mathrm{BC})$ have a resemblance to the global brightening and dimming phenomenon. Ohmura (2009) argued that the contributions from aerosols and clouds to the global dimming phase are roughly equal based on the transmittance data at several sites around the world. Tsutsumi and Murakami (2012) stress the possible role of clouds, especially those arising from aerosol-cloud interactions, in shaping global dimming and brightening in Japan. A few studies show that cloud effects are more dominant contributors to the secular SSR changes (e.g., Liepert, 2002, for the United States; Liley, 2009, for New Zealand; Russak, 2009, for Estonia; Sanchez-Lorenzo and Wild, 2012, for Switzerland during the dimming period). The preceding discussion indicates that the answer to the question as to whether a secular SSR change is caused by aerosols or clouds is yet equivocal and varies across regions as well as periods. Our argument below proceeds with the premise that global dimming and brightening in Japan is mainly caused by aerosols (including the effect from aerosol-cloud interactions) rather than clouds.

A remarkable feature in the observed all-sky SSR is the magnitude of its decadal change, which is about $15 \mathrm{~W} \mathrm{~m}^{-2}$ in Europe and up to $25 \mathrm{~W} \mathrm{~m}^{-2}$ in Japan during 1960-1990 (Skeie et al., 2011). It is a subject of debate that the observed decadal SSR trends are generally stronger than those simulated by a number of models, although such trends in several different regions of the world are qualitatively well reproduced by some models (Ruckstuhl and Norris, 2009; Dwyer et al., 2010; Folini and Wild, 2011; Skeie et al., 2011; Wild and Schmucki, 2011; Allen et al., 2013). From both model and observational perspectives, hypotheses have been put forward to explain the discrepancy between the observed and simulated SSR trends as summarized below:

From the model perspective, four conceivable reasons are (a) the resolutions of the models used in these studies are too coarse to capture the effects of local air pollution on SSR (Skeie et al., 2011), (b) the models do not describe aerosol and cloud effects and their interactions sufficiently (Skeie et al., 2011; Allen et al., 2013), (c) historical aerosol emission inventories are incorrect (Ruckstuhl and Norris, 2009; Folini and Wild, 2011; Allen et al., 2013), and (d) inaccurate variations in the aerosol fields are used in the models (Wild and Schmucki, 2011).

From the observational perspective, the discrepancy may be explained by the fact that a large number of measurement stations are located within or close to populated areas. It can be hypothesized that the observed all-sky SSR decadal shifts may not be universal but rather locally confined urban effects from atmospheric pollution with the direct aerosol effects being predominant (Kvalevåg and Myhre, 2007). Other issues that have been raised include the measurement data quality in some regions (Tang et al., 2011; You et al., 2013; Wang,

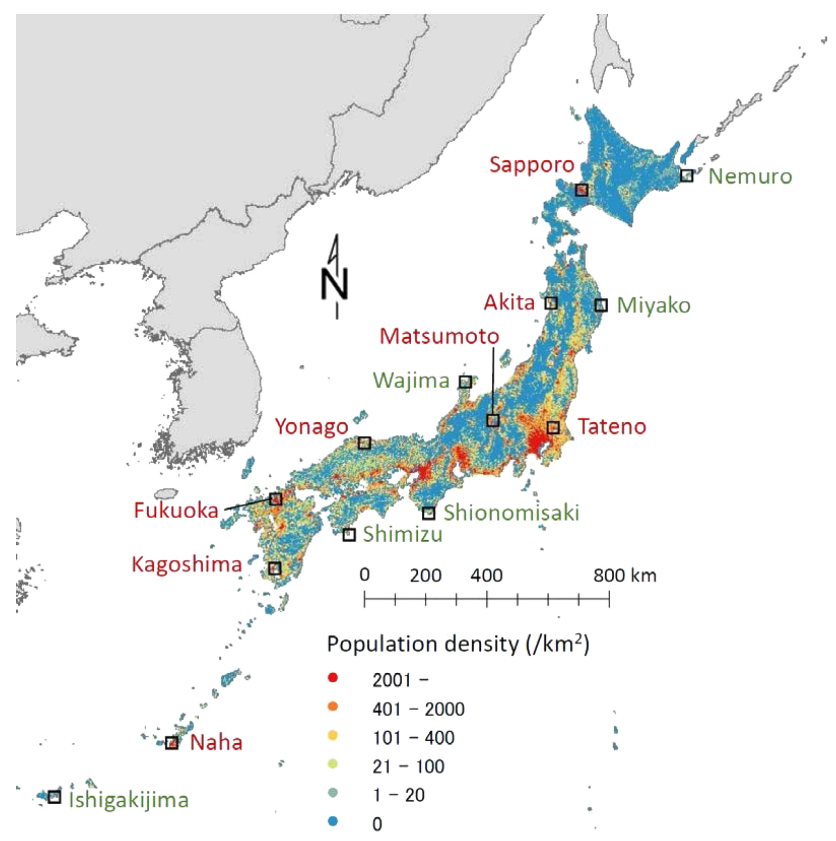

Figure 1. Locations and classifications of the 14 Japanese stations used in our analysis. The names of the polluted and pristine stations are indicated in red and green, respectively. The underlying population density distribution is based on the $1-\mathrm{km}$ grid data for the 2005 population census of Japan (http://e-stat.go.jp/SG2/eStatGIS/page/ download.html) and shown to indicate current urban areas.

2014) and the spatial representativeness of stations (Hakuba et al., 2013).

The answer is yet inconclusive and the question remains debated (Wild, 2009). While statistical studies estimating the level of human influence on SSR data based on demographic data claim that global dimming and brightening was limited to urban areas (Alpert et al., 2005; Alpert and Kishcha, 2008), several studies (Ramanathan et al., 2007; Stanhill and Cohen, 2009; Wang et al., 2014; Imamovic et al., 2016) questioned the validity of the underlying assumption that population was an effective proxy for human impacts on SSR. Furthermore, even if the geographical distribution of the stations is skewed strongly toward polluted locations, air pollution from urban areas would not be confined to the periphery of urban areas due to long-range transport as demonstrated by a number of observational and model- or satellite-based studies (e.g., Akimoto, 2003; Pinker et al., 2005; Lawrence et al., 2007; McConnell et al., 2007; Ramanathan et al., 2007; Yu et al., 2008, 2012, 2013; Folini et al., 2009; Monks et al., 2009; Lin et al., 2014). Furthermore, anthropogenic emissions from sources such as coal combustion and biomass burning are known to influence even the stratospheric aerosol levels (Hofmann et al., 2009; Solomon et al., 2011).

This study aims to contribute to the debate surrounding the observational perspective hypothesis. This study is a first attempt to clarify exclusively whether global dimming and 


\begin{tabular}{|c|c|c|c|c|c|c|c|c|c|}
\hline $\begin{array}{l}\text { Name / } \\
\text { Official name in } \\
\text { Japanese }\end{array}$ & $\begin{array}{l}\text { Jurisdiction / } \\
\text { full address in Japanese }\end{array}$ & $\begin{array}{l}\text { Latitude / } \\
\text { longitude }\end{array}$ & $\begin{array}{c}\text { Altitude } \\
(m)\end{array} \mid$ & $\begin{array}{l}\text { Year of foundation / } \\
\text { (year(s) of relocation) }\end{array}$ & $\begin{array}{c}\text { Radiation } \\
\text { measurement } \\
\text { method } \\
\text { during 1960s }\end{array}$ & $\begin{array}{l}\text { Current } \\
\text { staff } \\
\text { residence }\end{array}$ & $\begin{array}{c}\text { Municipality } \\
\text { area } \\
\left(\mathrm{km}^{2}\right)\end{array}$ & $\begin{array}{c}\text { Population } \\
\text { count and } \\
\text { density } \\
\left(/ \mathrm{km}^{2}\right)\end{array}$ & $\begin{array}{l}\text { Vehicle } \mathrm{CO}_{2} \text { emissions } \\
\left(\mathrm{tCO}_{2} / \text { year }\right) \\
\text { vehicles per capita }\end{array}$ \\
\hline $\begin{array}{c}\text { Akita } \\
\text { 秋田地方気象台 }\end{array}$ & \begin{tabular}{r|} 
Akita-city, Akita-pref. \\
秋田県秋田市山王 7-1-4
\end{tabular} & $\begin{array}{r}39^{\circ} 43.0^{\prime} \mathrm{N} \\
140^{\circ} 05.9^{\prime} \mathrm{E}\end{array}$ & 6.3 & $\begin{array}{r}1882 \\
\left(1886,1896,1926^{2}, 1989^{1}\right) \\
\end{array}$ & Robitzsch & Yes & 906.09 & $\begin{array}{r}323,600 \\
357\end{array}$ & $\begin{array}{r}672540 \\
0.53\end{array}$ \\
\hline $\begin{array}{c}\text { Fukuoka } \\
\text { 福岡管区気像台 }\end{array}$ & 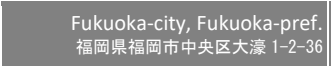 & $\begin{array}{r}33^{\circ} 34.9^{\prime} \mathrm{N} \\
130^{\circ} 22.5^{\prime} \mathrm{E}\end{array}$ & 2.5 & $\begin{array}{r}1889 \\
\left(1907^{2}, 1939^{1}\right)\end{array}$ & Eppley & Yes & 343.38 & $\begin{array}{r}1463743 \\
4263\end{array}$ & $\begin{array}{r}1996277 \\
0.37\end{array}$ \\
\hline $\begin{array}{c}\text { Kagoshima } \\
\text { 栫归島地方気象台 }\end{array}$ & $\begin{array}{r}\text { Kagoshima-city, Kagoshima-pref. } \\
\text { 鹿児照島県鹿归島市東郡元町 4-1 }\end{array}$ & $\begin{array}{r}31^{\circ} 33.3^{\prime} \mathrm{N} \\
130^{\circ} 32.8^{\prime} \mathrm{E} \\
\end{array}$ & 3.9 & $\begin{array}{r}1883 \\
\left(1897,1915^{2}, 1994^{1}\right) \\
\end{array}$ & Robitzsch & Yes & 547.57 & $\begin{array}{r}605846 \\
1106 \\
\end{array}$ & $\begin{array}{r}1160781 \\
0.49 \\
\end{array}$ \\
\hline $\begin{array}{c}\text { Matsumoto } \\
\text { 松本特别地域気象䧽測所 }\end{array}$ & $\begin{array}{r}\text { Matsumoto-city, Nagano-pref. } \\
\text { 長野県松本市沢村 1-7-13 }\end{array}$ & $\begin{array}{r}36^{\circ} 14.8^{\prime} \mathrm{N} \\
137^{\circ} 58.2^{\prime} \mathrm{E}\end{array}$ & 610 & $\begin{array}{r}1898^{2} \\
\left(1935^{1}\right)\end{array}$ & Robitzsch & $\begin{array}{r}\text { No } \\
(2007-)\end{array}$ & 978.47 & $\begin{array}{r}243037 \\
248\end{array}$ & $\begin{array}{r}493205 \\
0.58\end{array}$ \\
\hline $\begin{array}{l}\text { Naha } \\
\text { 沖縺気象台 }\end{array}$ & \begin{tabular}{r|} 
Naha-city, Okinawa-pref. \\
沖縺県那霸市㢦川I 1-15-15
\end{tabular} & $\begin{array}{r}26^{\circ} 12.4^{\prime} \mathrm{N} \\
127^{\circ} 41.2^{\prime} \mathrm{E} \\
\end{array}$ & 28.1 & $\begin{array}{r}1890^{7}\left(1925^{6}, 1927^{5}\right. \\
\left.1950^{4}, 1951^{3}, 1953^{2}, 1987^{1}\right)\end{array}$ & Robitzsch & Yes & 39.57 & $\begin{array}{r}315765 \\
7980\end{array}$ & $\begin{array}{r}320972 \\
0.38\end{array}$ \\
\hline $\begin{array}{c}\text { Sapporo } \\
\text { 札幌管区気象台 }\end{array}$ & $\begin{array}{l}\text { Sapporo-city, Hokkaido-pref. } \\
\text { 北海道札幌市中央区北 } 2 \text { 条西 18-2 }\end{array}$ & $\begin{array}{r}43^{\circ} 03.6^{\prime} \mathrm{N} \\
141^{\circ} 19.7^{\prime} \mathrm{E}\end{array}$ & 17.4 & $\begin{array}{r}1876 \\
\left(1878^{3}, 1890^{2}, 1939^{1}\right)\end{array}$ & Eppley & Yes & 1121.26 & $\begin{array}{r}1913545 \\
1707\end{array}$ & $\begin{array}{r}2961534 \\
0.41\end{array}$ \\
\hline $\begin{array}{c}\text { Tateno } \\
\text { 高層気象台 }\end{array}$ & \begin{tabular}{r|} 
Tsukuba-city, Ibaraki-pref. \\
茨城県つくば高峰 1-2
\end{tabular} & $\begin{array}{r}36^{\circ} 03.4^{\prime} \mathrm{N} \\
140^{\circ} 07.5^{\prime} \mathrm{E}\end{array}$ & 25.2 & $\begin{aligned} 1920^{1} \\
\text { (none) }\end{aligned}$ & Eppley & Yes & 283.72 & $\begin{array}{r}214590 \\
756\end{array}$ & $\begin{array}{r}327686 \\
0.57\end{array}$ \\
\hline $\begin{array}{c}\text { Yonago } \\
\text { *⿻丷木大子特別地域气象䧽測所 }\end{array}$ & \begin{tabular}{|c|} 
Yonago-city, Tottori-pref. \\
鳥取県米子市博学町 4-309-1
\end{tabular} & $\begin{array}{r}35^{\circ} 26.0^{\prime} \mathrm{N} \\
133^{\circ} 20.3^{\prime} \mathrm{E}\end{array}$ & 6.5 & $\begin{aligned} 1939^{1} \\
\text { (none) }\end{aligned}$ & Robitzsch & $\begin{array}{r}\text { No } \\
(2008-)\end{array}$ & 132.42 & $\begin{array}{r}148271 \\
1120\end{array}$ & $\begin{array}{r}314391 \\
0.56\end{array}$ \\
\hline $\begin{array}{c}\text { Ishigakijima } \\
\text { 石坦島地方気象台 }\end{array}$ & \begin{tabular}{r|} 
Ishigaki-city, Okinawa-pref. \\
沖絙県石坦市字登野城 428 \\
\end{tabular} & $\begin{array}{r}24^{\circ} 20.2^{\prime} \mathrm{N} \\
124^{\circ} 09.8^{\prime} \mathrm{E} \\
\end{array}$ & 5.7 & $\begin{array}{r}1896 \\
\left(1897^{1}\right) \\
\end{array}$ & Robitzsch & Yes & 229.27 & $\begin{array}{r}46922 \\
205 \\
\end{array}$ & $\begin{array}{r}41212 \\
0.42 \\
\end{array}$ \\
\hline $\begin{array}{c}\text { Miyako } \\
\text { 宮古特別地域気象镜測所 } \\
\end{array}$ & \begin{tabular}{r|} 
Miyako-city, Iwate-pref. \\
岩手県宮古市銭ヶ崎下町 2-33 \\
\end{tabular} & $\begin{array}{r}39^{\circ} 38.8^{\prime} \mathrm{N} \\
141^{\circ} 57.9^{\prime} \mathrm{E} \\
\end{array}$ & 42.5 & $\begin{array}{r}1883 \\
\left(1939^{2}, 1990^{1}\right) \\
\end{array}$ & Robitzsch & $\begin{array}{r}\text { No } \\
(2007-)\end{array}$ & 1259.15 & $\begin{array}{r}5,430 \\
47 \\
\end{array}$ & $\begin{array}{r}90727 \\
\text { N/A }\end{array}$ \\
\hline $\begin{array}{c}\text { Nemuro } \\
\text { 根室特别地域気象䧽測所 }\end{array}$ & $\begin{array}{r}\text { Nemuro-city, Hokkaido-pref. } \\
\text { 北海道根室市弥栄町 1-18 }\end{array}$ & $\begin{array}{r}43^{\circ} 19.8^{\prime} \mathrm{N} \\
145^{\circ} 35.1^{\prime} \mathrm{E}\end{array}$ & 25.2 & $\begin{array}{r}1879 \\
\left(1886^{1}\right)\end{array}$ & Robitzsch & $\begin{array}{r}\text { No } \\
(2010-)\end{array}$ & 506.25 & $\begin{array}{r}29201 \\
58\end{array}$ & $\begin{array}{r}101753 \\
0.56\end{array}$ \\
\hline $\begin{array}{c}\text { Shimizu } \\
\text { 清水特別地域気象観測所 }\end{array}$ & \begin{tabular}{r|} 
Tosashimizu-city, Kouchi-pref. \\
高知県土佐清水市足晢岬 605
\end{tabular} & $\begin{array}{r}32^{\circ} 43.3^{\prime} \mathrm{N} \\
133^{\circ} 00.6^{\prime} \mathrm{E}\end{array}$ & 31 & $\begin{aligned} 1940^{1} \\
\text { (none) }\end{aligned}$ & Robitzsch & $\begin{array}{r}\text { No } \\
(2007-)\end{array}$ & 266.34 & $\begin{array}{r}16029 \\
60\end{array}$ & $\begin{array}{r}28353 \\
0.46\end{array}$ \\
\hline $\begin{array}{c}\text { Shionomisaki } \\
\text { 潮俚特别地域気象魏測所 }\end{array}$ & $\begin{array}{l}\text { Kushimoto-town, Wakayama-pref. } \\
\text { 和歌山県東牟婁郡本本町潮㞳 3380-1 }\end{array}$ & $\begin{array}{r}33^{\circ} 27.0^{\prime} \mathrm{N} \\
135^{\circ} 45.4^{\prime} \mathrm{E}\end{array}$ & 67.5 & $\begin{array}{r}1912^{3} \\
\left(2009^{1}\right)\end{array}$ & Robitzsch & $\begin{array}{r}\text { No } \\
(2009-)\end{array}$ & 135.67 & $\begin{array}{r}18249 \\
135\end{array}$ & $\begin{array}{r}30329 \\
\text { N/A }\end{array}$ \\
\hline $\begin{array}{c}\text { Wajima } \\
\text { 輪島特别地域気象覣測所 }\end{array}$ & $\begin{array}{l}\text { Wajima-city, Ishikawa-pref. } \\
\text { 石川県輪島市風至町畠田 99-3 }\end{array}$ & $\begin{array}{r}37^{\circ} 23.4^{\prime} \mathrm{N} \\
136^{\circ} 53.7^{\prime} \mathrm{E}\end{array}$ & 5.2 & $\begin{array}{r}1896 \\
\left(1921,1929^{1}\right)\end{array}$ & Robitzsch & $\begin{array}{r}\text { No } \\
(2010-)\end{array}$ & 426.32 & $\begin{array}{r}29858 \\
70\end{array}$ & $\begin{array}{r}67305 \\
0.50\end{array}$ \\
\hline
\end{tabular}

Figure 2. Information that characterizes the 14 observatories under study. Rows for the eight polluted and six pristine observatories are indicated in red and green, respectively. Columns for those directly related to the observatories and those describing the surroundings are indicated in yellow and blue, respectively. Listed for each observatory are the municipality, prefecture, and current address in Japanese (http:// www.data.jma.go.jp/svd/eqev/data/kyoshin/jma_sindo.html) (note that station addresses are only partially made available on other websites), followed by the latitude, longitude, and altitude (m) of the current station location obtained from the JMA website (http://www.data.jma.go.jp/ $\mathrm{obd} / \mathrm{stats} / \mathrm{etrn} / \mathrm{index} . \mathrm{php}$ ) and the years of foundation and relocation(s) extracted from the activity records of meteorological stations in Japan. It then indicates the type of radiation measurement instrument used during the 1960s (Eppley- or Robitzsch-type pyranometers), which had been in place before being replaced with thermopile pyranometers in the early 1970s at all sites. The next column indicates whether staffs are resident at sites based on information available at the JMA website (http://www.data.jma.go.jp/obd/stats/data/kaisetu/shishin/shishin_3.pdf). Subsequently, this figure shows the municipality area $\left(\mathrm{km}^{2}\right)$ (http://www.gsi.go.jp/KOKUJYOHO/MENCHO/201410/opening.htm), 2010 census population count, population density (per km ${ }^{2}$ ), vehicle $\mathrm{CO}_{2}$ emissions $\left(\mathrm{tCO}_{2}\right.$ year $^{-1}$ ) in 2003 (http://www.colgei.org/CO2/), and the number of registered vehicles (including light automobiles, so called K-cars) per capita in 2011 (Sangyochiiki_Kenkyusho, 2012). Vehicle $\mathrm{CO}_{2}$ emissions are based on the number of registered vehicles in each municipality combined with assumptions on the average trip distance and the emission coefficient for each of several different vehicle types. Information shown above is for the current sites unless noted otherwise.

brightening in Japan has been observed only in urban areas. To do so, we look into the data for SSR and maximum/zenith transmittance and inspect if there are any significant differences between their temporal trends over urban areas and those over rural areas.

Our approach can be characterized in comparison to other studies as below:

Earlier studies (e.g., Imamovic et al., 2016) deal with a large number of observatories worldwide (on the order of hundreds) that provide all-sky SSR data. In contrast, this study focuses on a small set of stations in Japan (only 14 stations) (Fig. 2) that yield not only SSR data but also transmittance data. This gives our approach an advantage to separate aerosol and cloud effects. Locations of the 14 stations analyzed in our study cover most of Japan homogeneously.

While a few earlier studies (e.g., Alpert et al., 2005; Alpert and Kishcha, 2008) rely primarily on population data to infer the influence of urbanization on SSR measurements, we collect and utilize as much information as possible to overcome possible limitations for population-based proxies when they are applied to infer the air pollution level (Ramanathan et al., 2007; Stanhill and Cohen, 2009; Wang et al., 2014; Imamovic et al., 2016). These include historical land use maps, recent satellite images, and current photographs taken during actual site visits. Such geographical information has not been included in the debate associated with the causes 


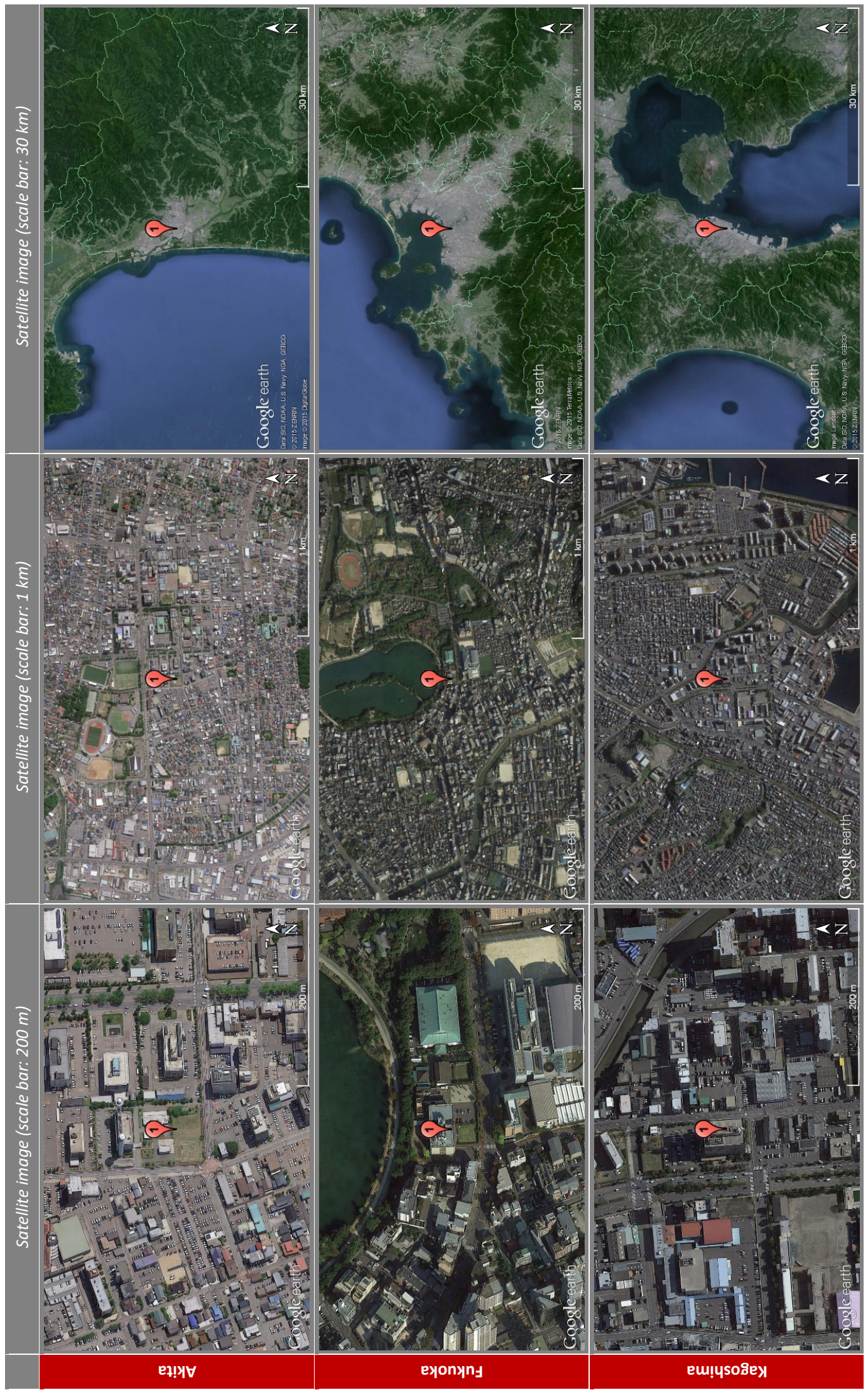

Figure 3. 


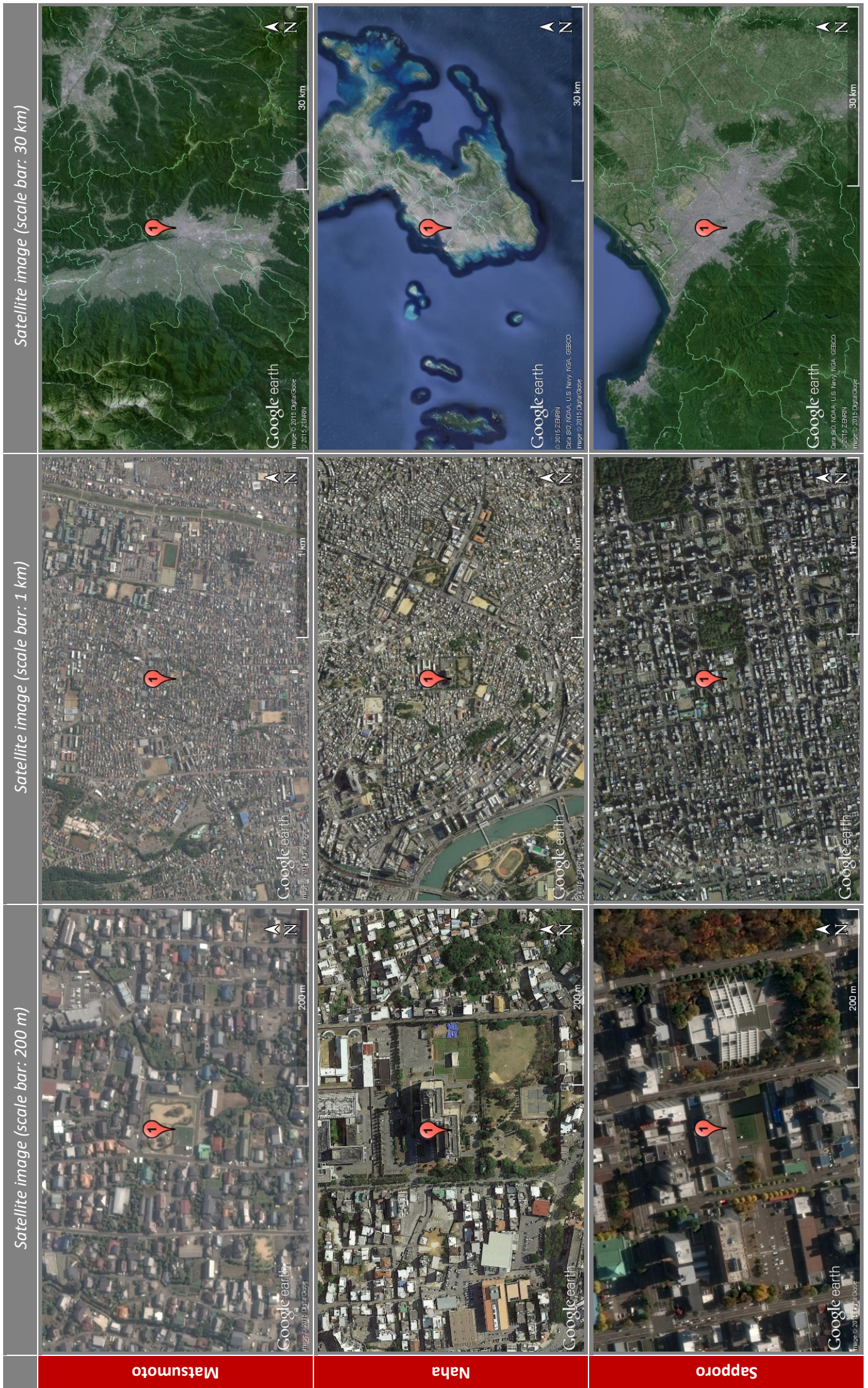

Figure 3. 


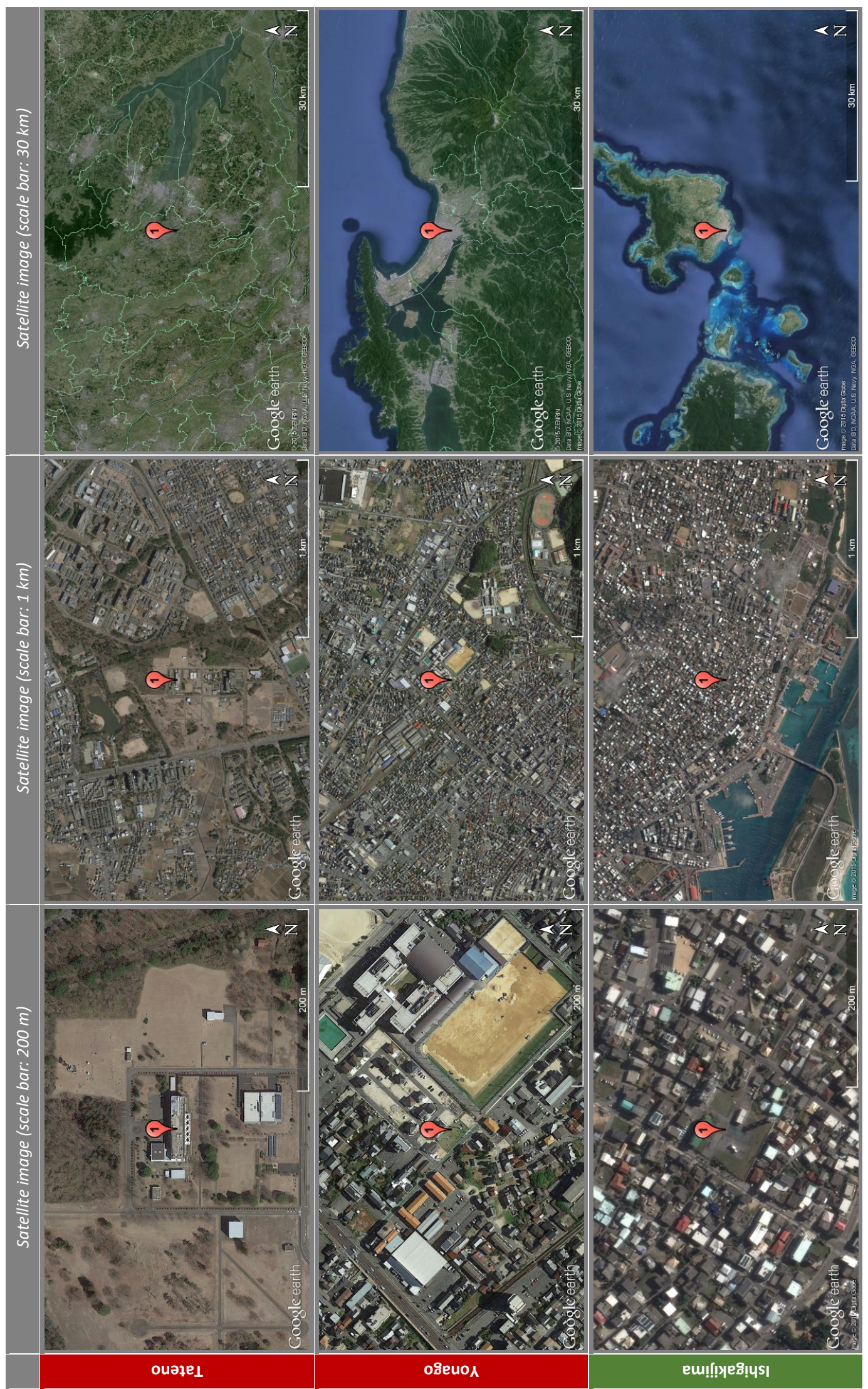

Figure 3. 


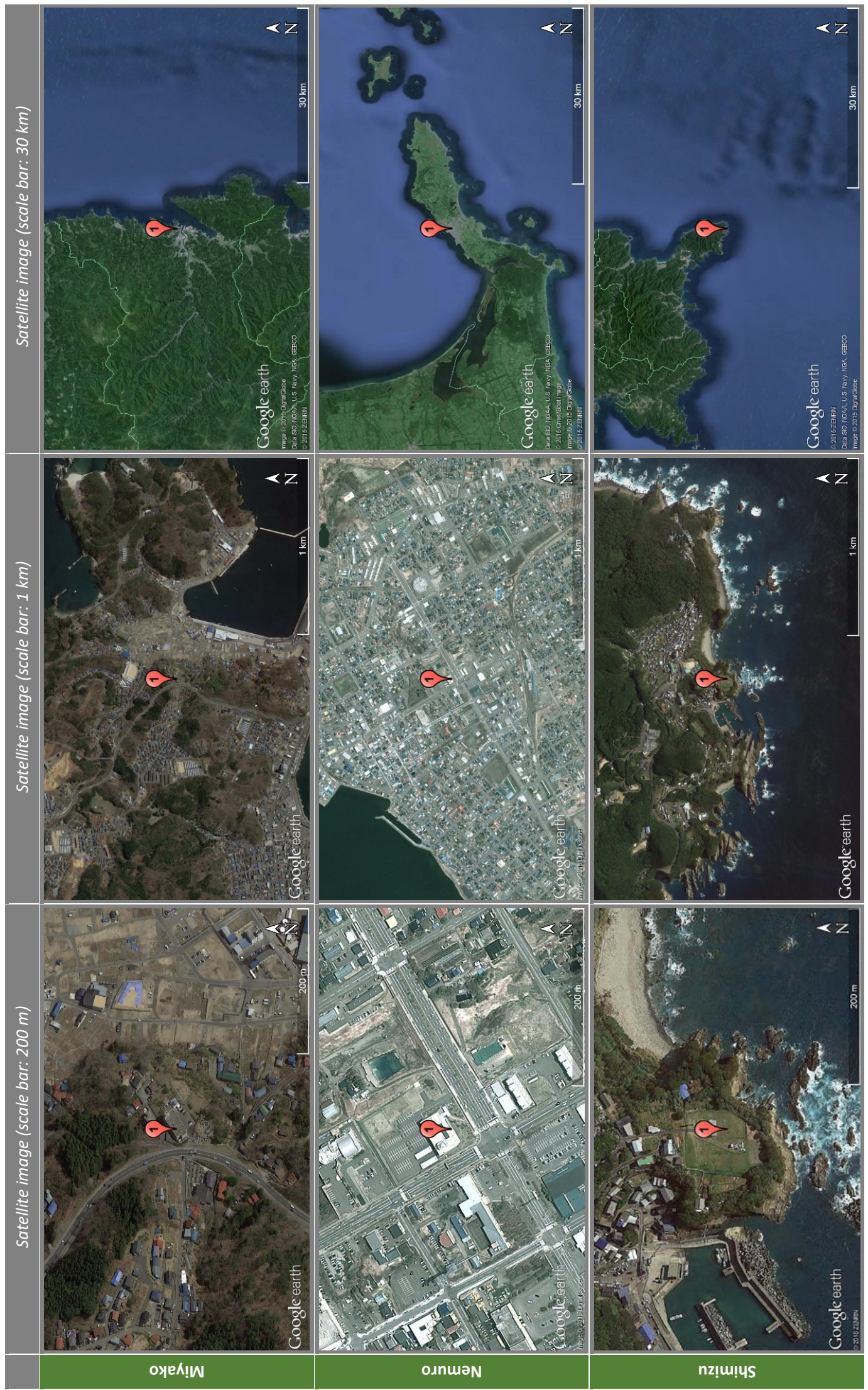

Figure 3. 


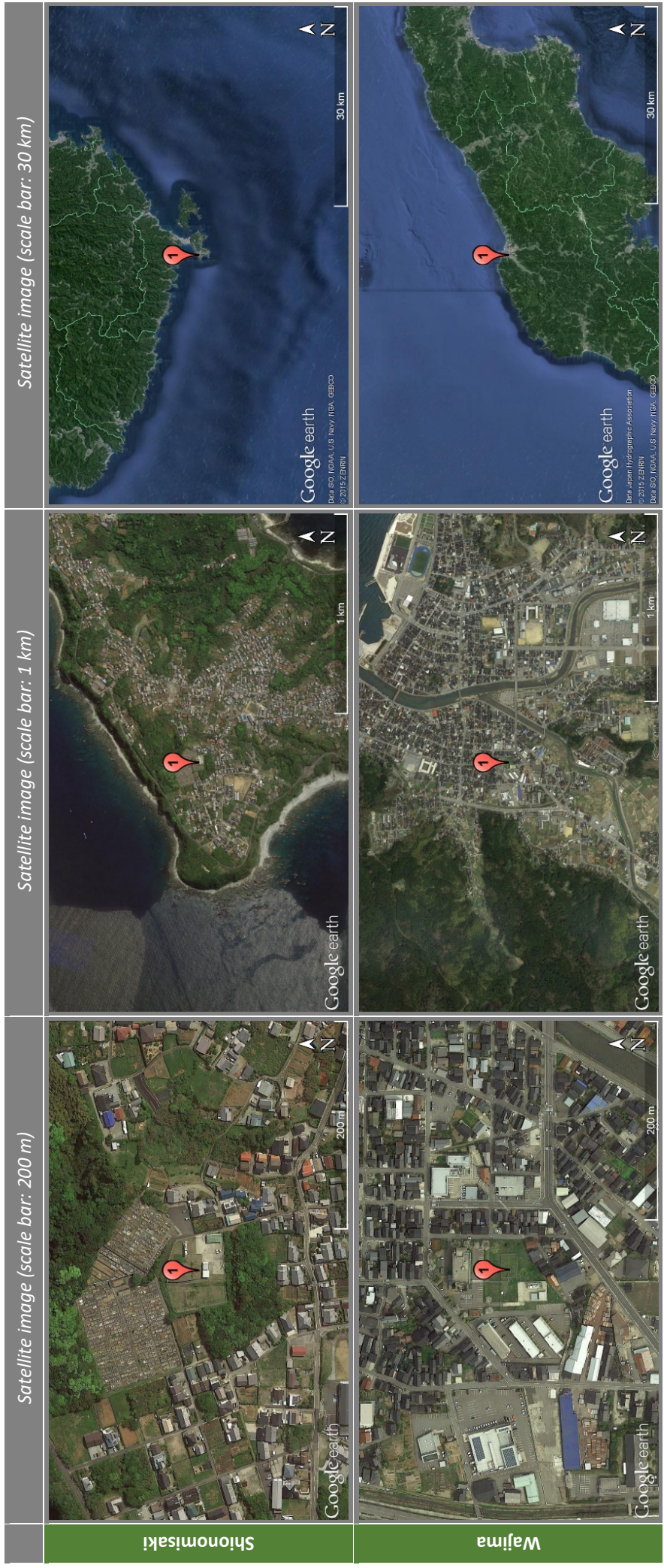

Figure 3. Satellite images surrounding the 14 stations under study. Rows for the eight polluted and six pristine observatories are indicated in red and green, respectively. Satellite images were retrieved from Google Earth Pro on 8 December 2015. The images were taken from satellites during 2012-2015. For each site, images are presented in three different scales: one showing the immediate surroundings, such as buildings, housing, roads, and parks (scale bar $=200 \mathrm{~m}$ ); another showing the land use at the district level (scale bar $=1 \mathrm{~km}$ ); and the other largely covering the municipality area of interest (scale $b a r=30 \mathrm{~km}$ ). The exact locations of the stations, which are marked as red balloons, are based on the postal addresses available at http://www.data.jma.go.jp/svd/eqev/data/kyoshin/jma_sindo.html. Green lines indicate current municipality boundaries and grey lines indicate prefectural boundaries. It should be noted that the area surrounding the Miyako station was heavily affected by the 2011 Tōhoku earthquake and tsunami in Japan (see Fig. 4 for previously taken images). 


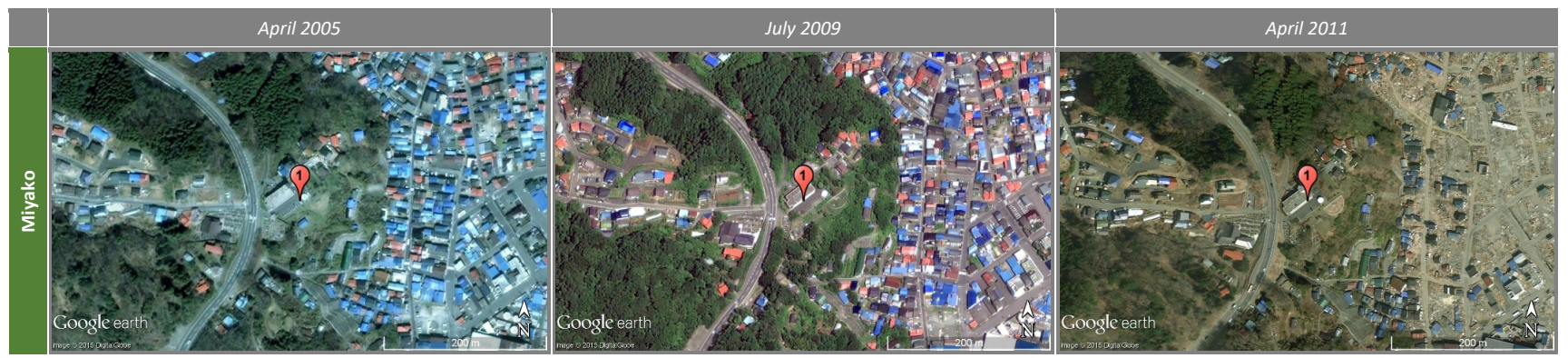

Figure 4. Satellite images surrounding the Miyako station taken in April 2005, July 2009, and April 2011. Satellite images were retrieved from Google Earth Pro on 8 December 2015. The length of the scale bar is $200 \mathrm{~m}$. See the caption for Fig. 3.

of global dimming and brightening. Furthermore, we look to station-specific historical information (e.g., site relocations and measurement instruments) compiled from archived documents. Such pieces of information, particularly those during the previous century, are not digitalized and are practically inaccessible without dedicated efforts.

For the specific case of Japan, there are two related studies (Norris and Wild, 2009; Kudo et al., 2012). Both studies derived aerosol and cloud effects in the Japanese SSR data, but none of them addressed the impacts from urbanization, which we focus on. Kudo et al. (2012) employ a method to estimate AOD and single scattering albedo from global and direct irradiance data measured at the same 14 stations. Norris and Wild (2009) use two different cloud datasets to estimate aerosol contributions to measured all-sky SSR levels. In contrast, our analysis directly makes use of the data for global SSR and zenith/maximum transmittance data.

The paper is organized as follows. In Sect. 2, we describe environmental changes surrounding the 14 stations based on available information and then classify the stations according to the inferred pollution levels. Such discussions on the station surroundings are reflected in Sect. 3, which discusses the temporal changes in SSR and the transmittance data in the urban and rural areas as well as at each individual station. Concluding remarks are provided in Sect. 4.

\section{States of urbanization surrounding the observatories}

\subsection{Data related to urbanization}

To investigate the possible effect of local air pollution on the observed SSR and transmittance, we separate the 14 Japanese stations into two groups: polluted and pristine stations (Fig. 1). The immediate surroundings of the former group are considered to have already been affected by urban development, while those of the latter are regarded as having been hardly influenced by urban development until present. More technically, a pristine station must satisfy both of the two "pristine conditions": (i) it is currently located away from cities and (ii) it has not seen any significant urban development in the peripheral region.

Our site classification is carried out on the basis of various sources of evidence at the municipality level. Indices that can be used as a proxy for urbanization are, however, generally scarce at the municipality level. There are no time series that directly capture the air pollution level on the municipality scale for a sufficiently long period of time for this study. Relevant data are more abundant at the prefectural level, but only those at the municipality level are meaningful for our analysis focusing on local pollution. We therefore resort to an educated guess based on available information at hand. In other words, because no existing single index can reliably and universally represent urbanization, we look to multiple lines of evidence. The evidence we use includes temporal changes in municipality population counts and densities since 1920 based on census (Figs. 10 and 11), vehicle $\mathrm{CO}_{2}$ emissions in 2003 (http://www.colgei.org/CO2/), the number of registered vehicles per capita in 2011 (Sangyochiiki_Kenkyusho, 2012) (Fig. 2), historical land use maps during three selected periods (1955-1960; 1975-1980; 1995-2000) (Figs. 5 and 6), recent satellite images taken during 2012-2015 (Fig. 3), and current photographs taken during the site visits in 2015 and 2016 (Fig. 9). While there are several different sources of evidence used to evaluate the first pristine condition discussed above, the second pristine condition can be investigated only by changes in population counts and densities, historical land use maps, and recent satellite images.

Population data are the most accessible and the only long time series available on such a fine scale (note that municipality population data before the 1970s are not systematically available in a digitalized format). There are, however, known limitations when they are interpreted as proxies for urbanization. The use of population alone as a proxy to infer the air pollution level is under debate (Alpert et al., 2005; Ramanathan et al., 2007; Alpert and Kishcha, 2008; Stanhill and Cohen, 2009; Wang et al., 2014; Imamovic et al., 2016). Related are issues associated with the use of population-based proxies to infer $\mathrm{CO}_{2}$ emissions (for an overview, see Andres et al., 2012), even though $\mathrm{CO}_{2}$ emissions are not necessar- 


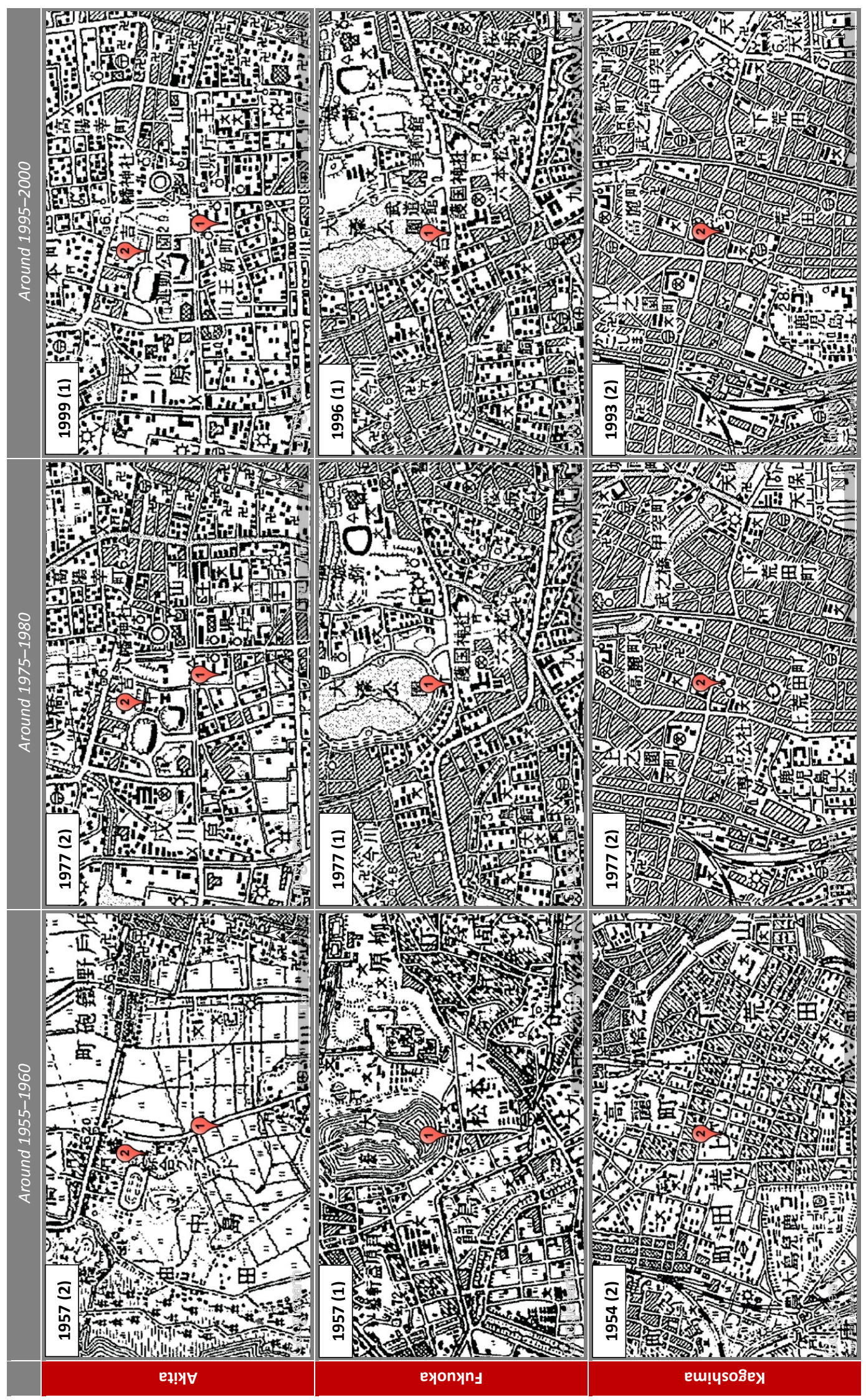

Figure 5. 


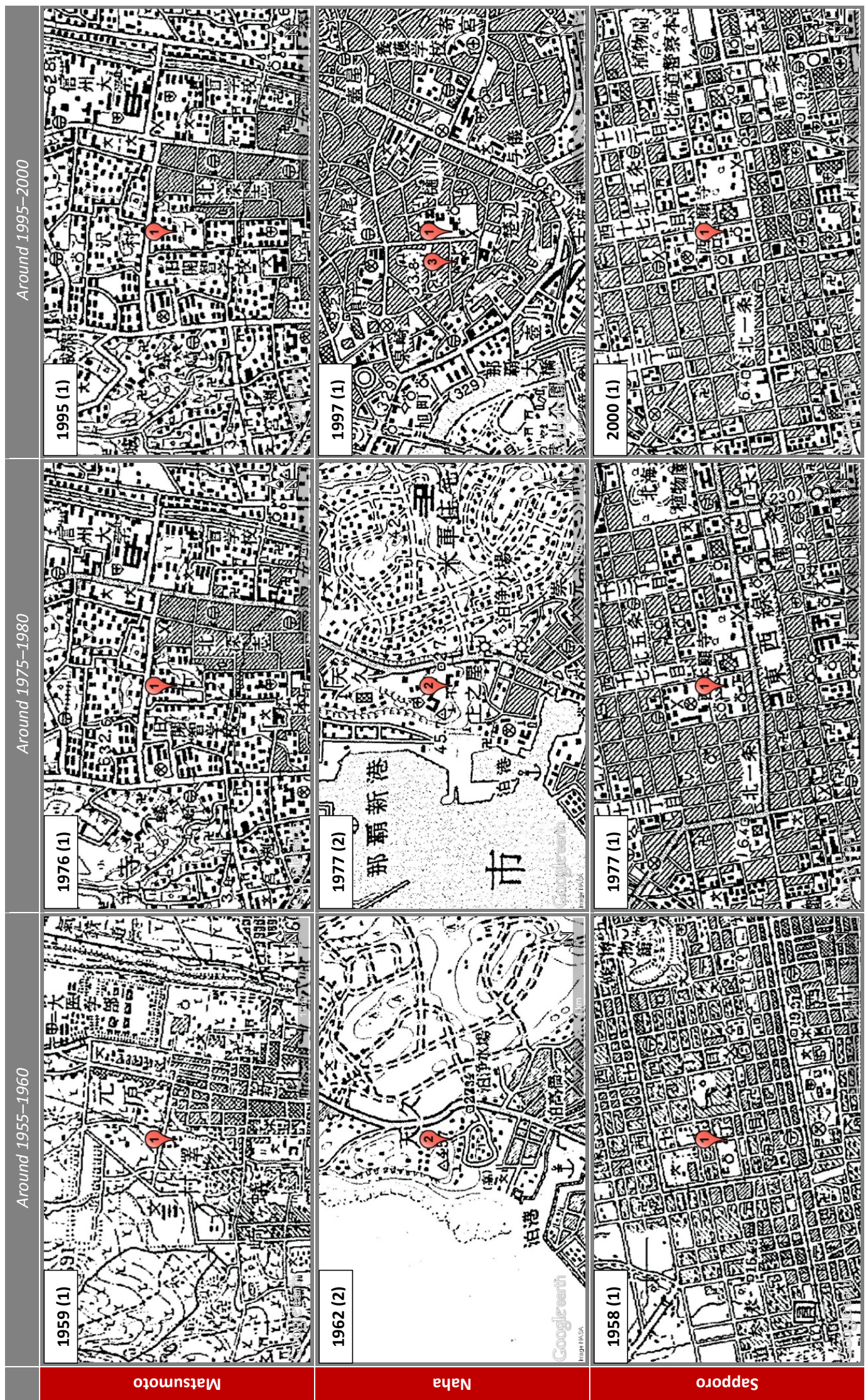

Figure 5. 


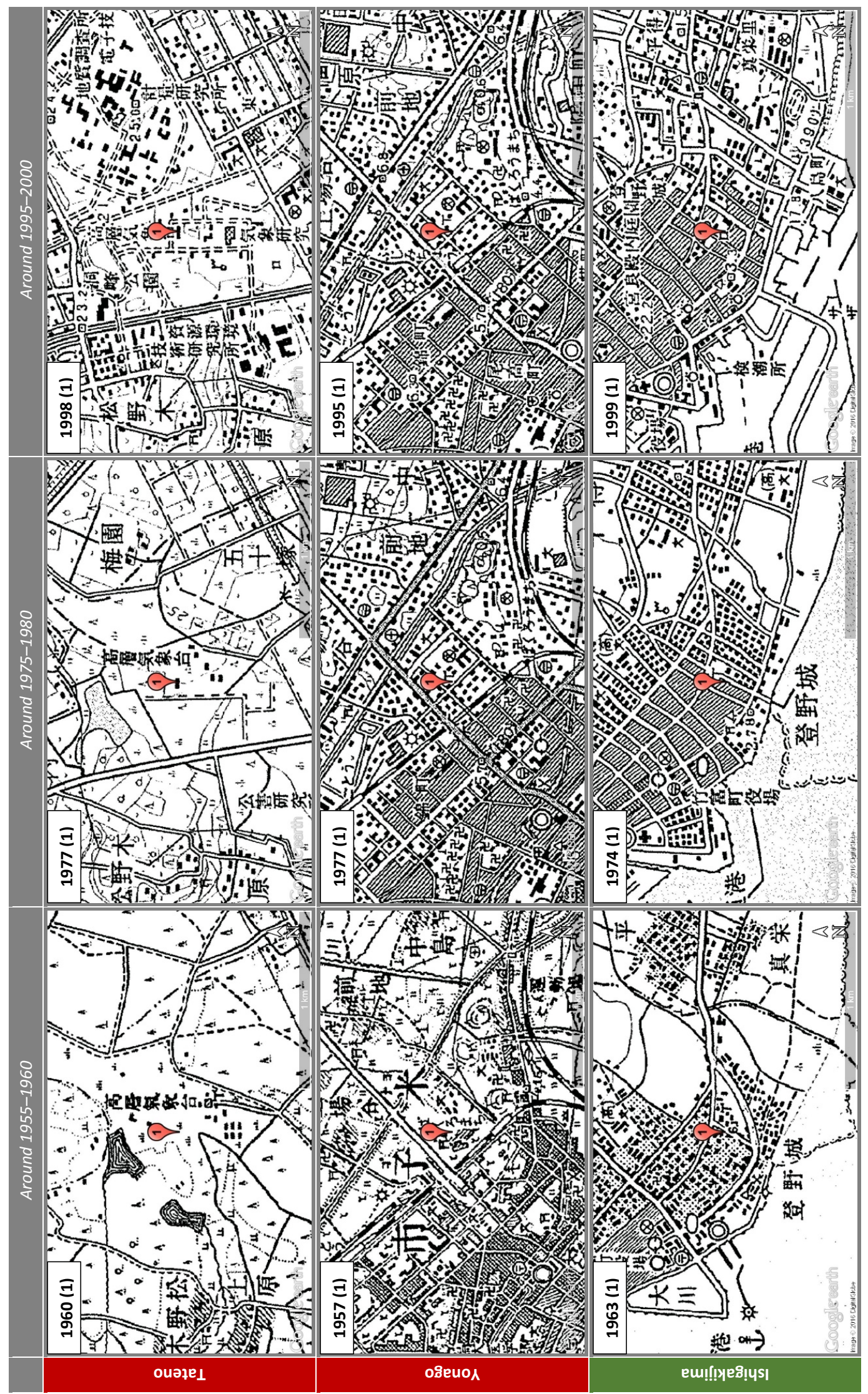

Figure 5. 


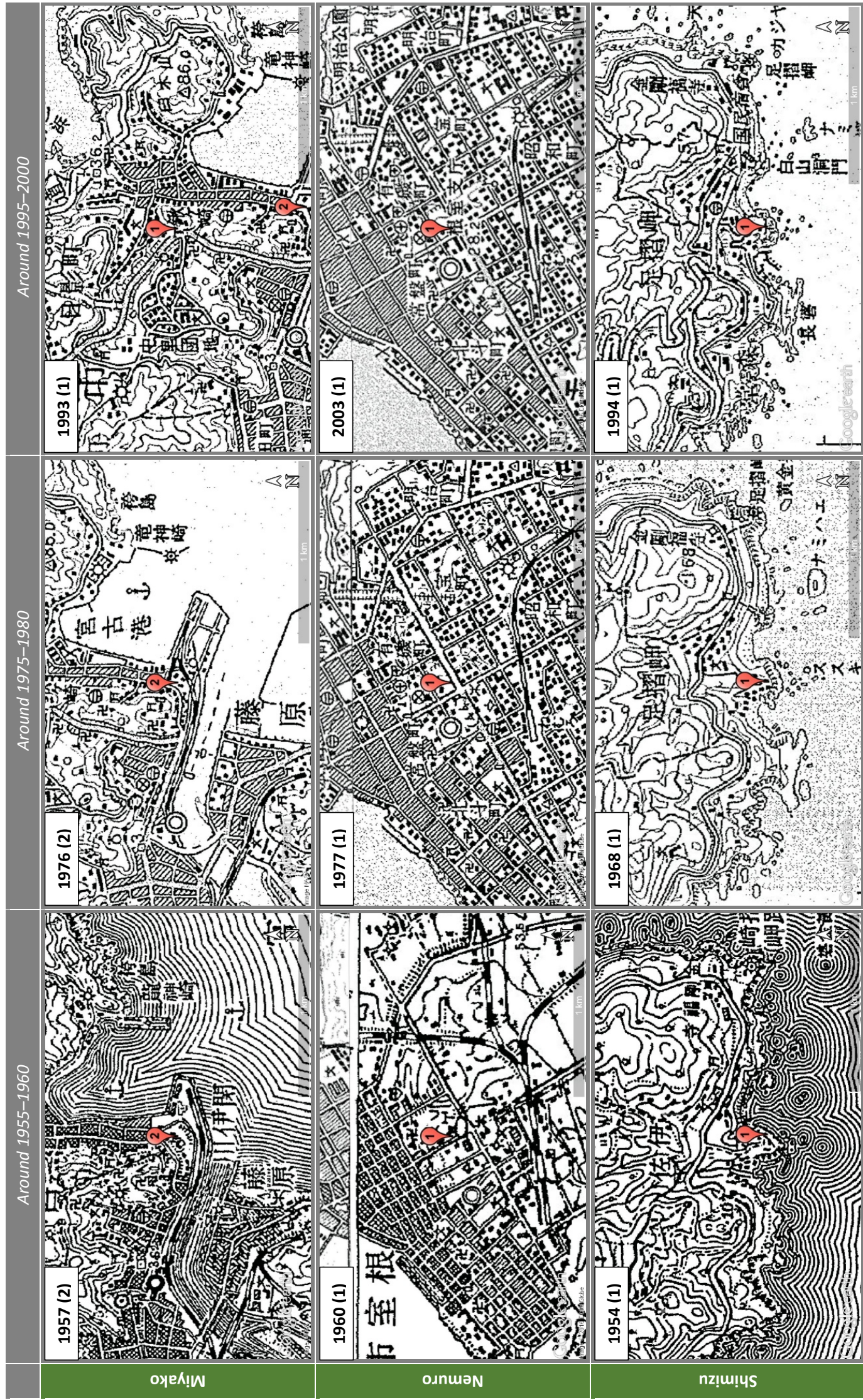

Figure 5. 


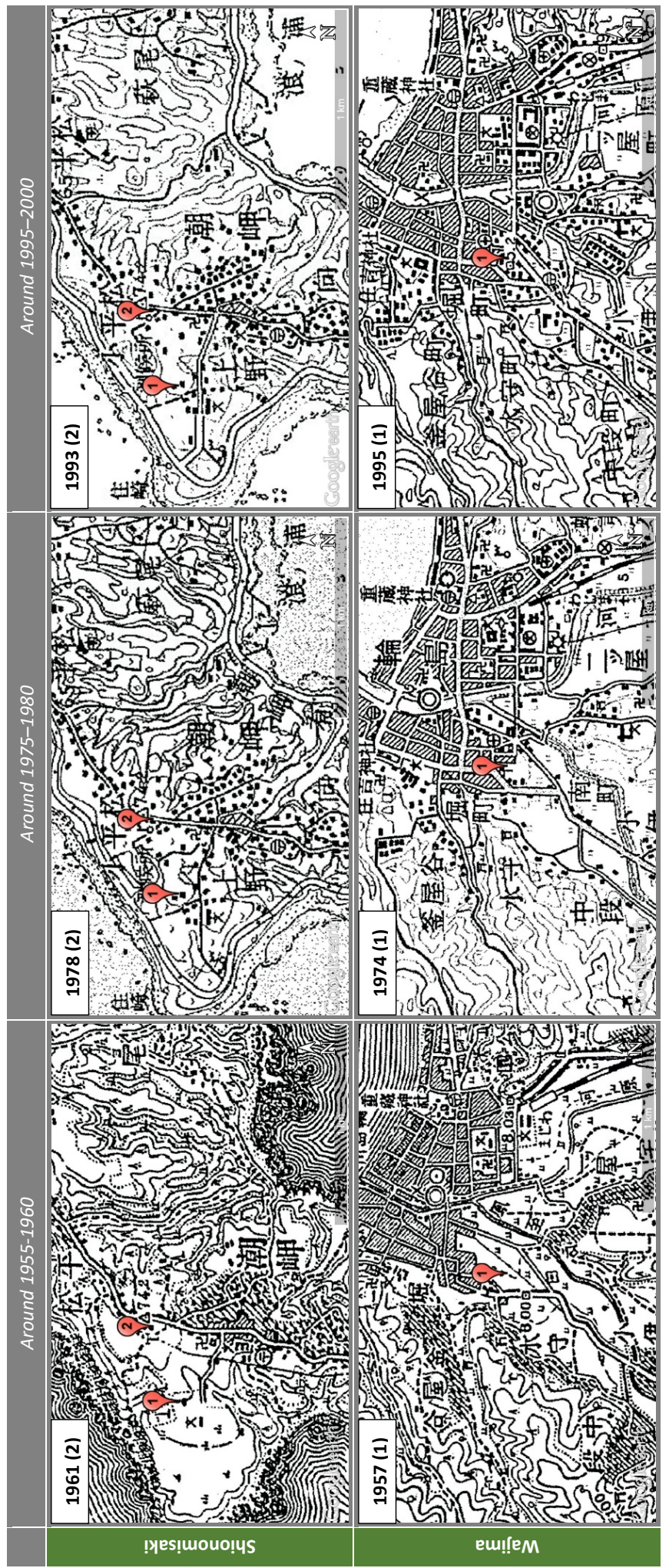

Figure 5. Chronological changes in land use surrounding the current and previous sites for the 14 observatories under study (length of the scale bar is $1 \mathrm{~km}$ ). Rows for the eight polluted and six pristine observatories are indicated in red and green, respectively. At the top left corner of each panel, the issue year of the map is indicated. The number in brackets after the map year is the designated number of the site in operation at the time of map publication. Hatched areas and solid dots are built-in areas and buildings/houses etc., respectively, indicating the area of urbanization. Sites are numbered from most current to oldest up to around the 1930s (see Fig. 2 for the periods of operation). Site locations are approximately shown and mainly based on the activity records of meteorological observatories in Japan. Only substantial physical relocations accompanied by address changes are shown on the map. In other words, minor changes in instrument locations within the same premises are not made explicit in the figure. References for the maps used in this figure can be found in Fig. 8 . 

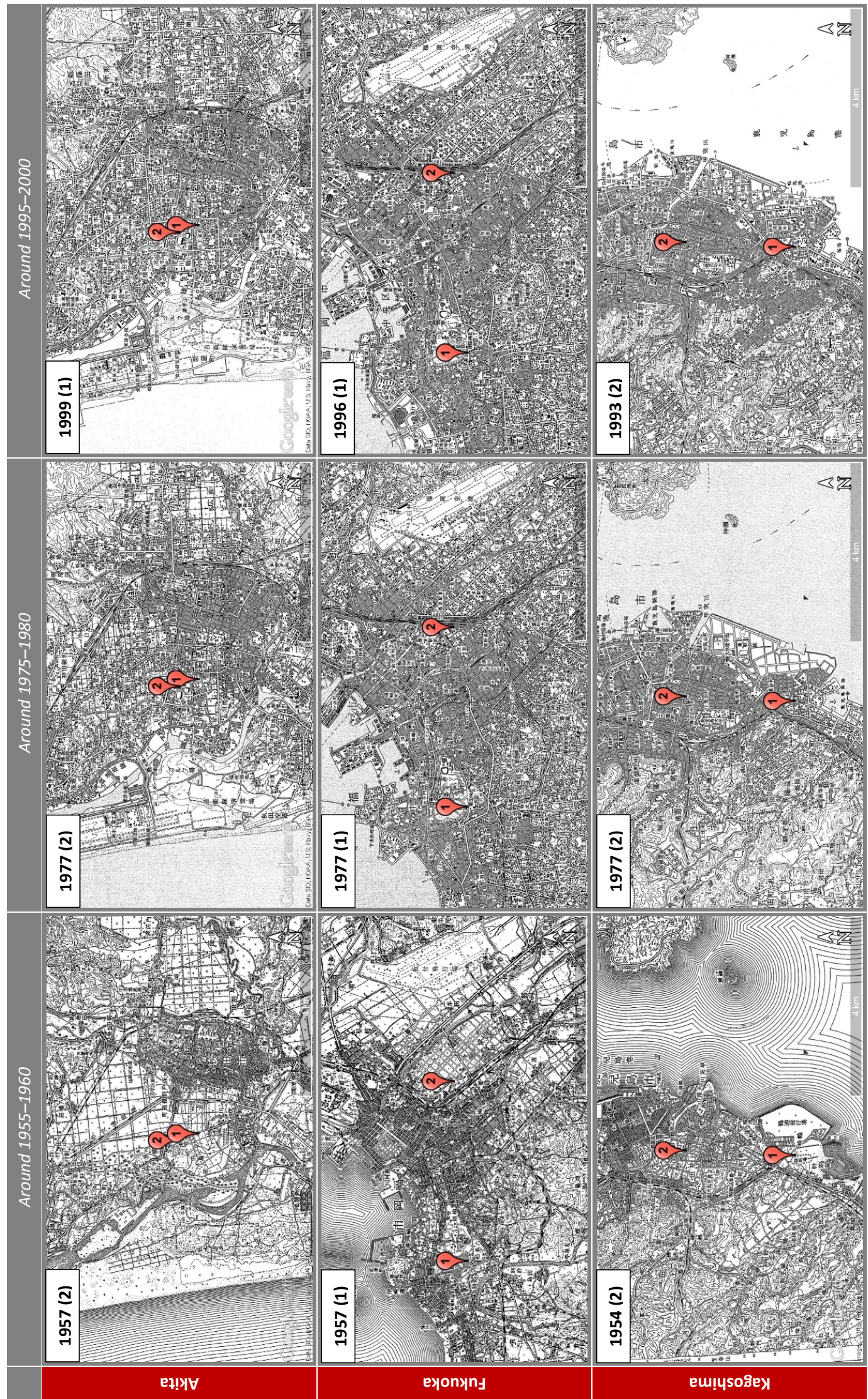

Figure 6. 


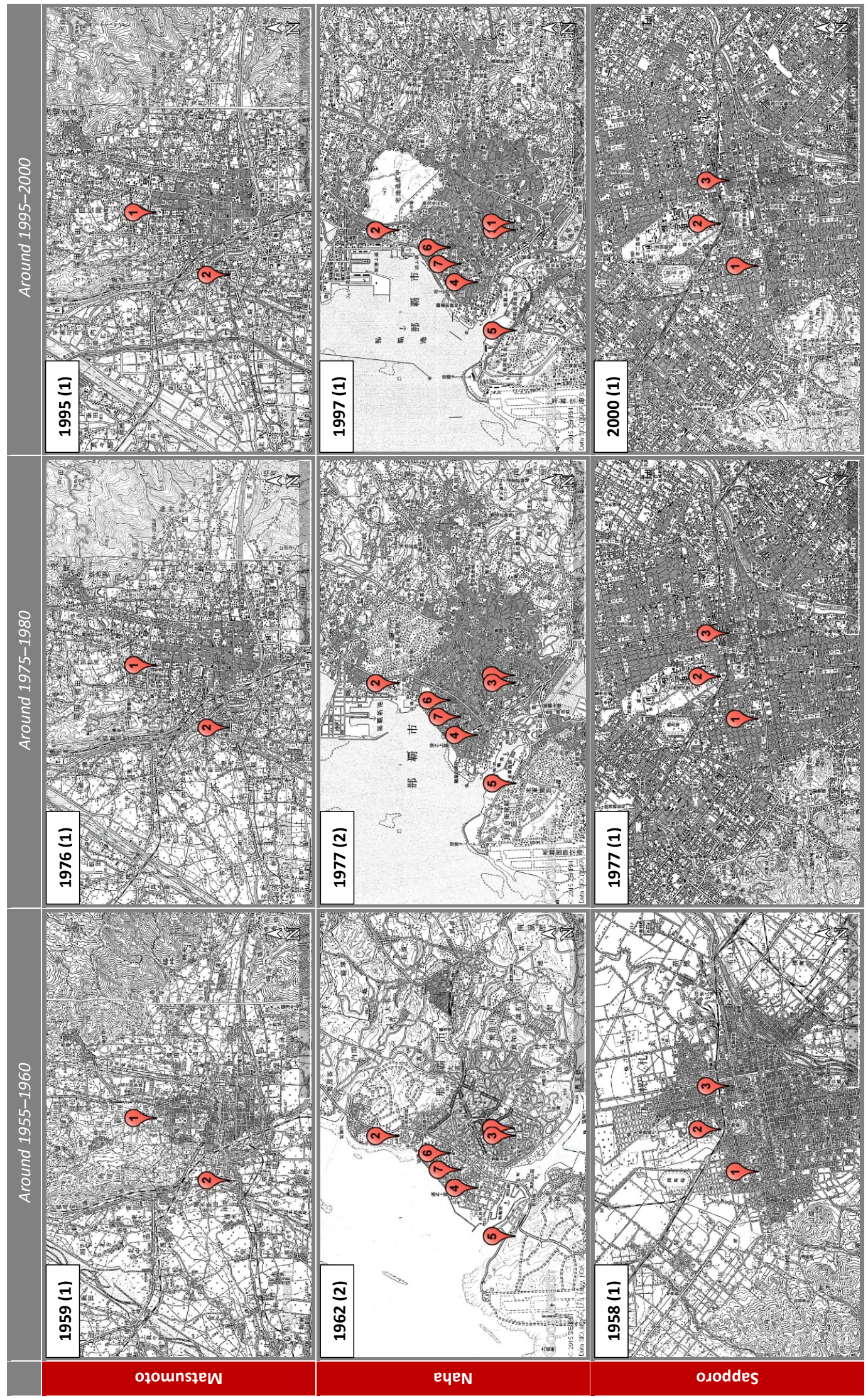

Figure 6. 


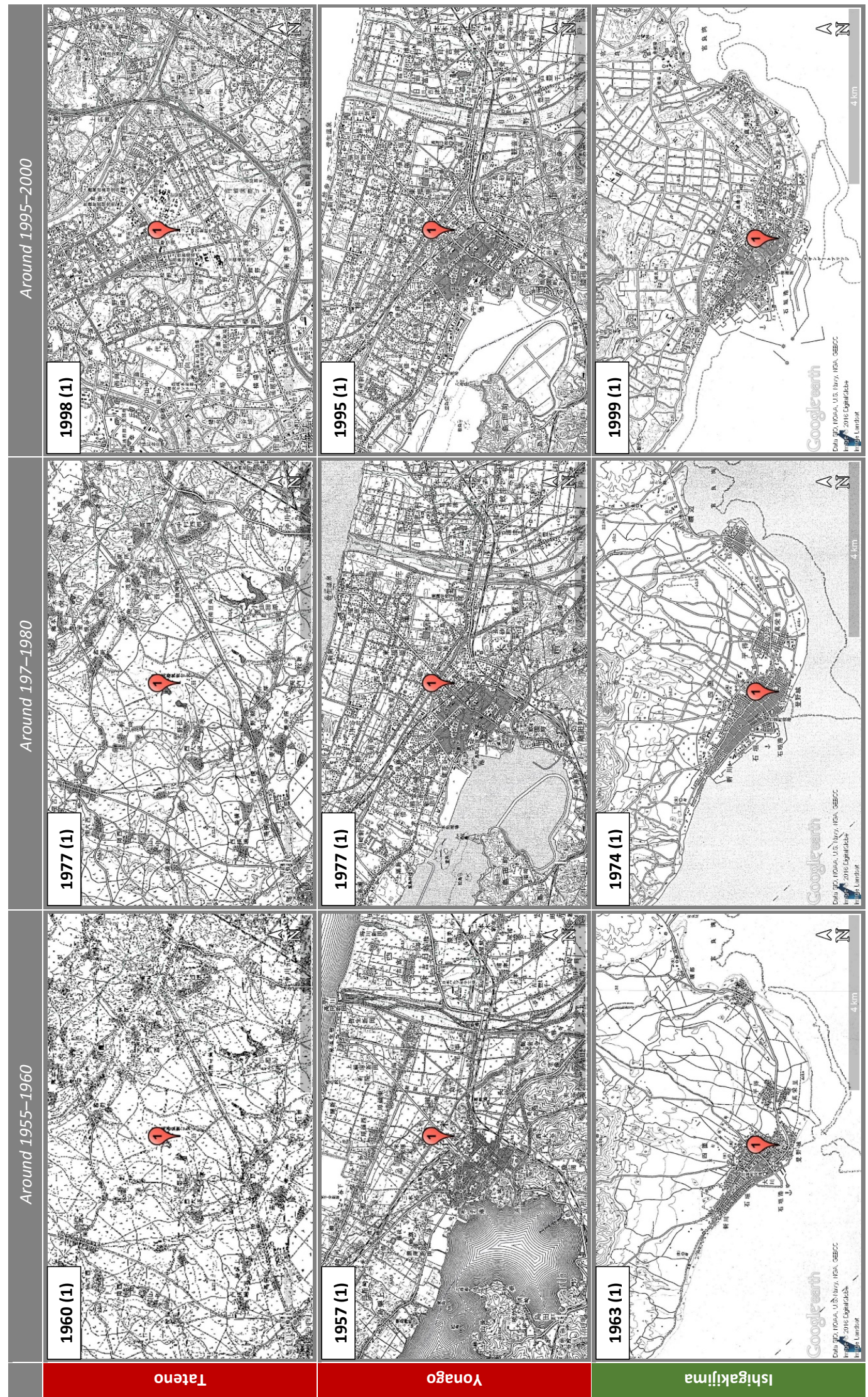

Figure 6. 


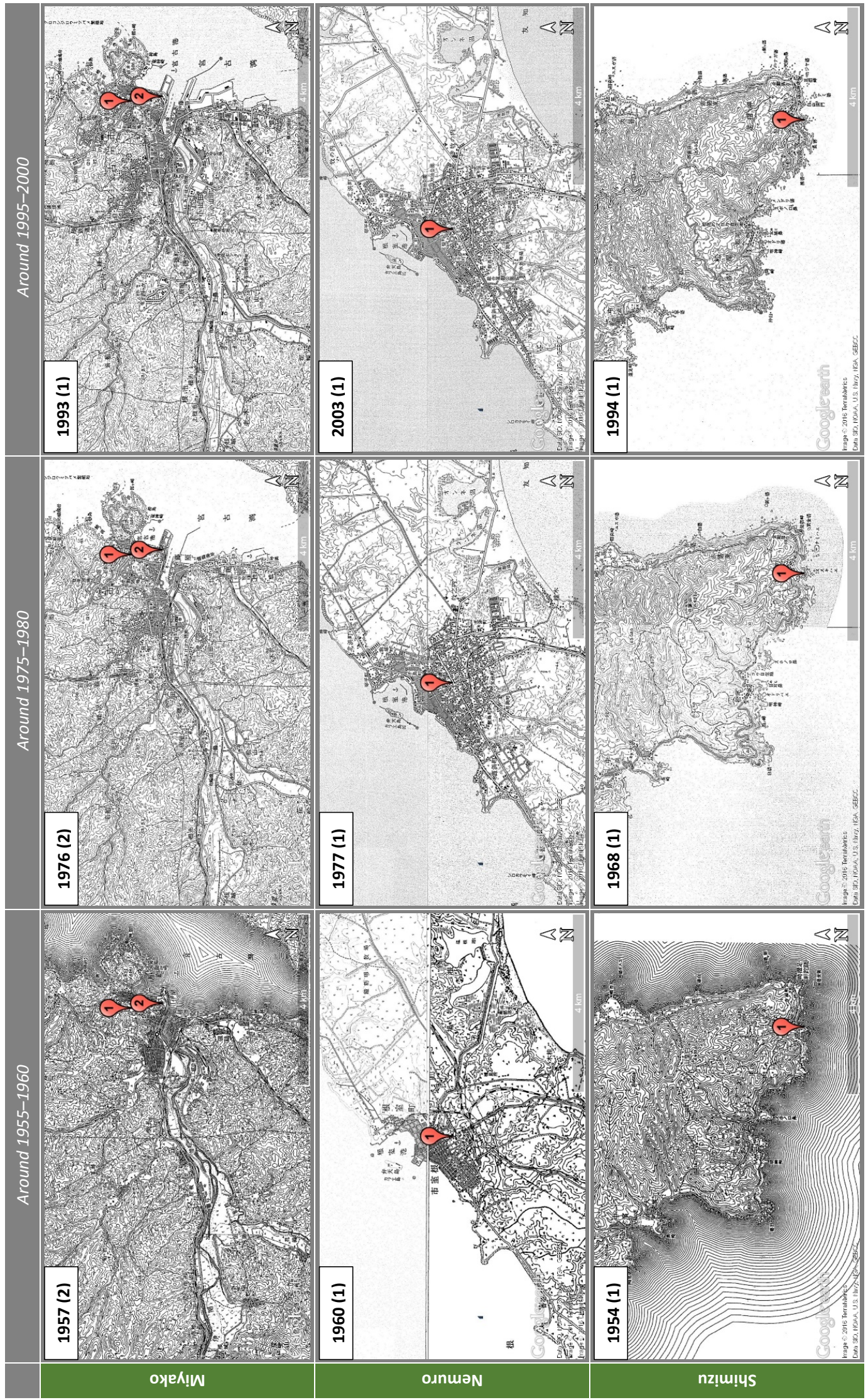

Figure 6. 


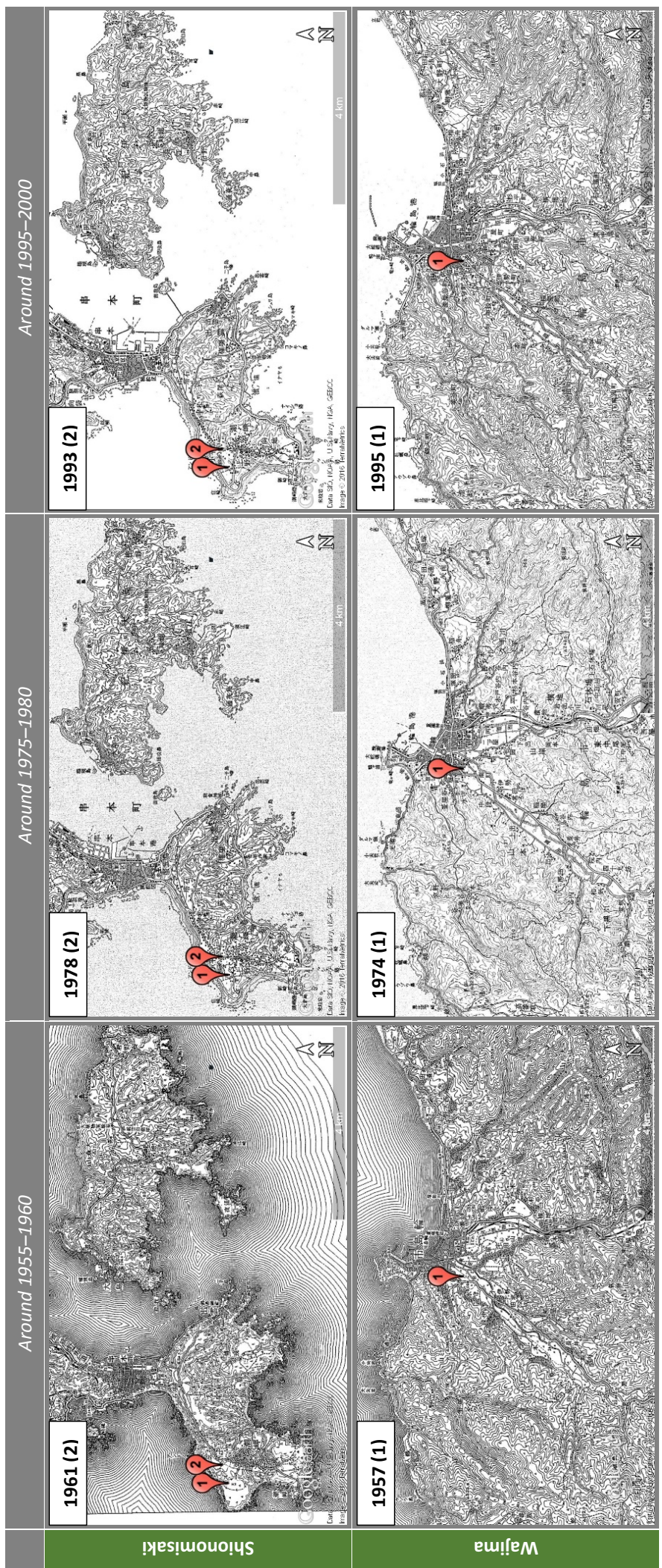

Figure 6. Chronological changes in land use surrounding the current and previous sites for the 14 observatories under study (length of the scale bar is $4 \mathrm{~km}$ ). See the caption for Fig. 5. 


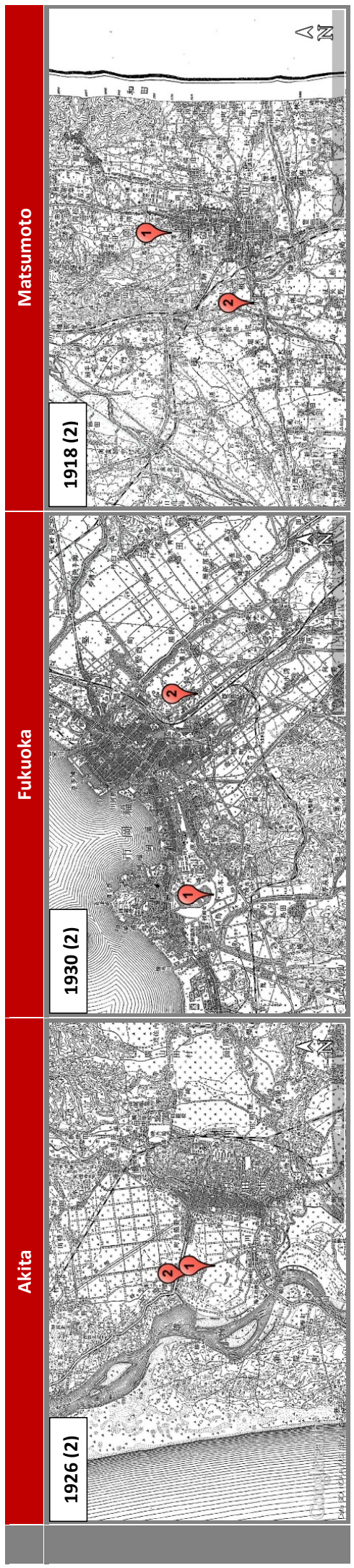

Figure 7. Land use changes at a few selected polluted sites (Akita, Fukuoka, and Matsumoto) in the early 20 th century. The length of the scale bar is $4 \mathrm{~km}$. These maps can be compared with the corresponding ones in Fig. 6. See the caption for Fig. 5 . ily correlated with $\mathrm{SO}_{2}$ emissions on the relevant spatial and time scales (Grossman and Krueger, 1995; Holtz-Eakin and Selden, 1995; Dinda, 2004). Population data may serve as a proxy for $\mathrm{CO}_{2}$ emissions from residential and commercial sectors but work poorly for emissions from power and transport sectors. With respect to power sectors, population fails to represent $\mathrm{CO}_{2}$ emissions when coal is combusted in a remote area to support the electricity demands in a distant urban area. This type of issues becomes important when one deals with emission data on a fine spatial scale. Concerning transport sectors, transport emissions per capita are known to decline above a certain population density threshold (Gately et al., 2015). In our analysis, the population time series are therefore complemented by the series of historical land use maps, recent satellite images, and current photographs, which provide additional insights into how the site surroundings have changed during the past period of interest.

We employ about 50 maps containing the locations of the 14 observatories under study (including previous site locations if relocated) (Fig. 8). Maps were selected to cover roughly three different windows of time: (i) 1955-1960, (ii) 1975-1980, and (iii) 1995-2000. Note, however, that some of the maps we use are slightly outside of these windows due to limited map availability. The choice of these time windows reflects our general observation that the urban development in many parts of Japan continued throughout the previous century, but in some areas it has slowed down after the 1980s, which is parallel to the period when clean air policies entered into effect across the country. One can thus compare the differences in the maps between periods (i) and (ii) with those between periods (ii) and (iii) in order to distill insights into how urbanization proceeded across the presumed turning point in peripherals of the sites. We only use maps in the scale of 1:50000 since maps in such a scale were more frequently updated during the past century than those in a finer scale of $1: 25000$. To offer different levels of perspective, each map is shown in two spatial scales: one with a scale bar length of $1 \mathrm{~km}$ (Fig. 5) and the other with a scale bar length of $4 \mathrm{~km}$ (Fig. 6). The maps we use were published from the Geospatial Information Authority of Japan (GSI) (or previous associated organizations for the maps before roughly 1960). Because maps of our interest are not available in a digital format, we scanned the paper maps at first. We then georeferenced the digitalized maps by using the software package QGIS and applying Google Earth Pro to present them geographically in relation to the current and previous site locations. These maps are supplemented by recent satellite images retrieved during the years 2012-2015, which were also obtained from Google Earth Pro. To provide a wider perspective, the satellite images are presented on three spatial scales (i.e., scale bar lengths are set at $200 \mathrm{~m}$, 1 , and $30 \mathrm{~km}$ ). It should be noted that the locations of some previous sites are only approximately shown on the maps and images because in some instances, the exact locations cannot be easily traced from the addresses in old formats. The ad- 
dress format was altered over a long period of time, due to municipality mergers and dissolutions, for instance, which we discuss below.

Another issue associated with municipality data is frequent changes in jurisdictional boundaries due to municipality mergers and dissolutions. Municipal mergers alone can mimic a population increase of the afflicted cities and towns in statistics. Over a long period of time, the number of municipalities in Japan has been reduced from 71314 (December 1888) to 1713 (December 2015). The last two decades saw a halving of the number of municipalities because of enhanced merger activities around 2005. We account for such boundary changes when compiling the time series of population counts and densities (Figs. 10 and 11) to highlight the biases that can be caused by boundary changes (Fig. 10). The frequent boundary changes place limitations on the usefulness of other time series at the municipality level even when they exist. For instance, data on the gross domestic production at the municipality level for the past several decades, which are available at some municipalities investigated in our analysis, are fraught with this problem.

Our educated guess about the possible urbanization impact on the SSR measurements draws on the experiences of A. Ohmura, a co-author who has been carrying out a long-term engagement in radiation measurements and has paid visits over the past several decades to a number of observatories around the world (Ohmura, 2009, 2014), as well as the recent activities of $\mathrm{K}$. Tanaka, the first author, who visited 7 sites out of the 14 under study (Akita, Matsumoto, Shimizu, Shionomisaki, Tateno, Yonago, and Wajima). To convey some impression of the present environments surrounding the sites, we present three photographs taken at and around each of the seven sites capturing the measurement fields and their immediate surroundings within a radius of a few hundred meters (Fig. 9). Changes in the immediate surroundings of the stations are crucial information for this study and available only by visiting the sites (e.g., see the discussion on Wajima in Sect. 2.2). We argue that the selection of meteorological stations appropriate for a long time series analysis requires a field investigation focusing on changes in the stations and their environments. For instance, changes in instrumentation and instrument locations are best available in the archives at meteorological headquarters as well as at sites. One should be cautious about studying only published statistics without visiting sites because relevant changes are often unnoticeable in statistics.

\subsection{Classification of the polluted and pristine stations}

With the preceding considerations, we arrived at six stations (i.e., Ishigakijima, Miyako, Nemuro, Shimizu, Shionomisaki, and Wajima) that had not been flagged for pollution. They thus qualified for the pristine group, while the remaining eight stations (i.e., Akita, Fukuoka, Kagoshima, Matsumoto, Naha, Sapporo, Tateno, and Yonago) fall into the polluted group. The rationales for such site classification are described below. For the sake of discussion, stations are described according crudely to the order of current development. It should be noted that there remains, however, evidence that favors the Ishigakijima and Wajima sites in the polluted group. To address such counter-evidences, we perform sensitivity analyses by changing the group compositions with respect to these sites.

There are two stations in large cities (Sapporo and Fukuoka): it is virtually certain that Sapporo and Fukuoka observatories have been affected by urbanization. These stations are located within major cities in Japan, whose current populations are above 1000000 (Fig. 2) and whose built-in areas are extensive in space (Fig. 1), which leads to a violation of the first pristine condition introduced in Sect. 2.1. Both of the stations have been in operation at their respective current locations without any relocations since 1939 (Fig. 2). The rapid expansion of Sapporo came during the first half of the 20th century and slowed down around 1980 (Figs. 5 and 6 ), which is also evident in the trends of population count and density (Figs. 10 and 11). The development of Fukuoka increased later during the last century (Fig. 6) accompanied by the steady population growth until present (Fig. 10). Such city growths were considered as violations of the second pristine condition.

There is one station in a medium-size city (Kagoshima): the station is located in a medium-size city (current population: about 600000 ) and characterized by the large population density and vehicle $\mathrm{CO}_{2}$ emissions (Fig. 2). The city occupies a large area (Fig. 1). Visual inspection of the land use changes and the population trends (Figs. 5, 6, 10, and 11) suggested that the city growth has continued until present but declined since the 1980s. The site was moved in 1994 within a distance of a few kilometers (Fig. 2).

There are five stations in small cities (Akita, Matsumoto, Naha, Tateno, and Yonago): these stations are found in smaller cities (current population of about 150 000-300 000) and are discussed one by one in alphabetical order in the following paragraphs.

In Akita the previous (1926-1989) and current (1989present) sites are located within a business district and just a few hundred meters away from the prefecture government building. Highways pass around the current site and there are large above-ground parking lots nearby (Figs. 1, 3, and 7 ). Both the previous and current sites have been gradually swallowed by the surrounding urban development (Figs. 5 and 6).

Matsumoto, among other sites under study, is the only site located at a relatively high altitude $(610 \mathrm{~m})$. The current site has been in operation since 1935 (Fig. 2). The series of historical land use maps (Figs. 5 and 6) show that Matsumoto has gradually expanded to the area encompassing the site. The immediate surrounding area of the site is currently residential, punctuated by a few tall apartments (Fig. 9). Roads 

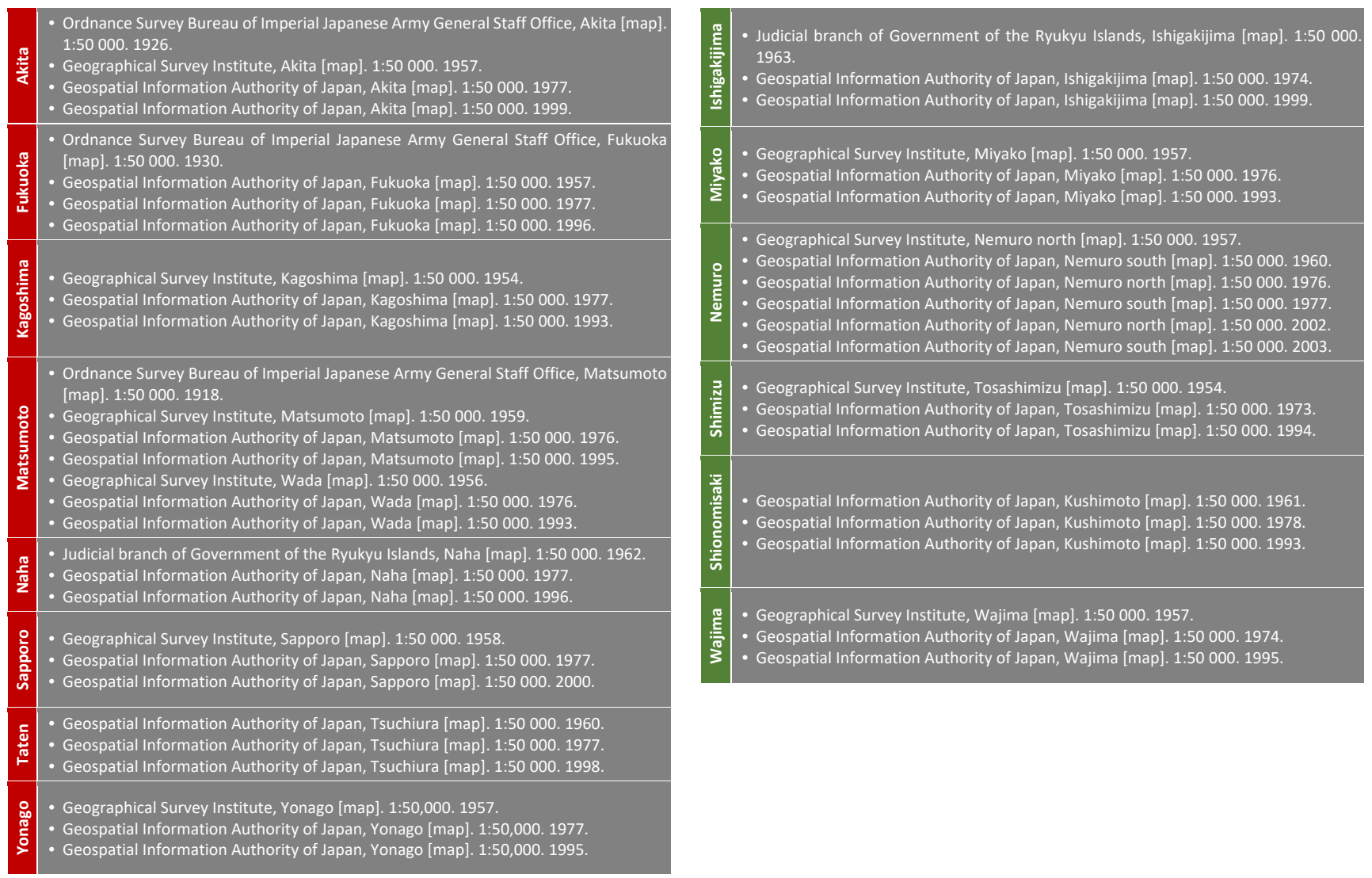

Figure 8. References for the maps used in Figs. 5, 6, and 7. Rows for the eight polluted and six pristine observatories are indicated in red and green, respectively.

with relatively heavy traffic passing by the Shinshu University campus run about a few hundred meters away (Fig. 5).

Although Naha is relatively small in terms of population count, the city currently has the highest population density among the 14 municipalities in spite of its location away from the Japanese mainland (Fig. 2). The population count and density of Naha grew rapidly during 1950-1975 (Figs. 10 and 11). The observatory was relocated just once during the study period but was moved several times previously (Figs. 2 and 6), as discussed earlier as an extreme case of station relocations.

The Tateno site is located in Tsukuba, a city newly developed for research and development, whose major transport mode is vehicles, as indicated by the relatively large number of vehicles per capita (Fig. 2). The site has been invaded by urban development that took off around the 1960s, although it is not as dense as in the other major urban areas. Currently there is a major road passing relatively close to the site (Figs. 1, 5, and 9). The site location has been stable since its inauguration in 1920 (Fig. 2).

Yonago is located in a currently remote area of Japan. The city area has gradually spread over the site during the past century (Figs. 5 and 6). The population density in Yonago has been as high as that in Kagoshima since around 1980 (Figs. 2 and 11). The site has not been moved for a long period of time (Fig. 2). The immediate surrounding area of the site is residential, but there are major roads about a few hundred meters away from the site (Figs. 1, 5, and 9).

There are six stations in rural areas (Ishigakijima, Miyako, Nemuro, Shimizu, Shionomisaki, and Wajima): no strong indication was found that air pollution could have affected these six sites. Remarks for each station are given in alphabetical order below.

The Ishigakijima station is regarded as a pristine site based primarily on the expert judgment of A. Ohmura. In spite of its distant location from the Japanese mainland, visual inspection of the land use maps (Fig. 6) indicated signs of smallscale urbanization that has taken place around the site. While the projection of population count in Ishigakijima is more comparable with that associated with other pristine stations (Fig. 10), the projection of population density in Ishigakijima is close to that in Matsumoto, a polluted station (Fig. 11). The category of this station is thus subject to a sensitivity analysis.

For the past 50 years the population density of Miyako has been the lowest of the sites considered here (Fig. 11) and the 


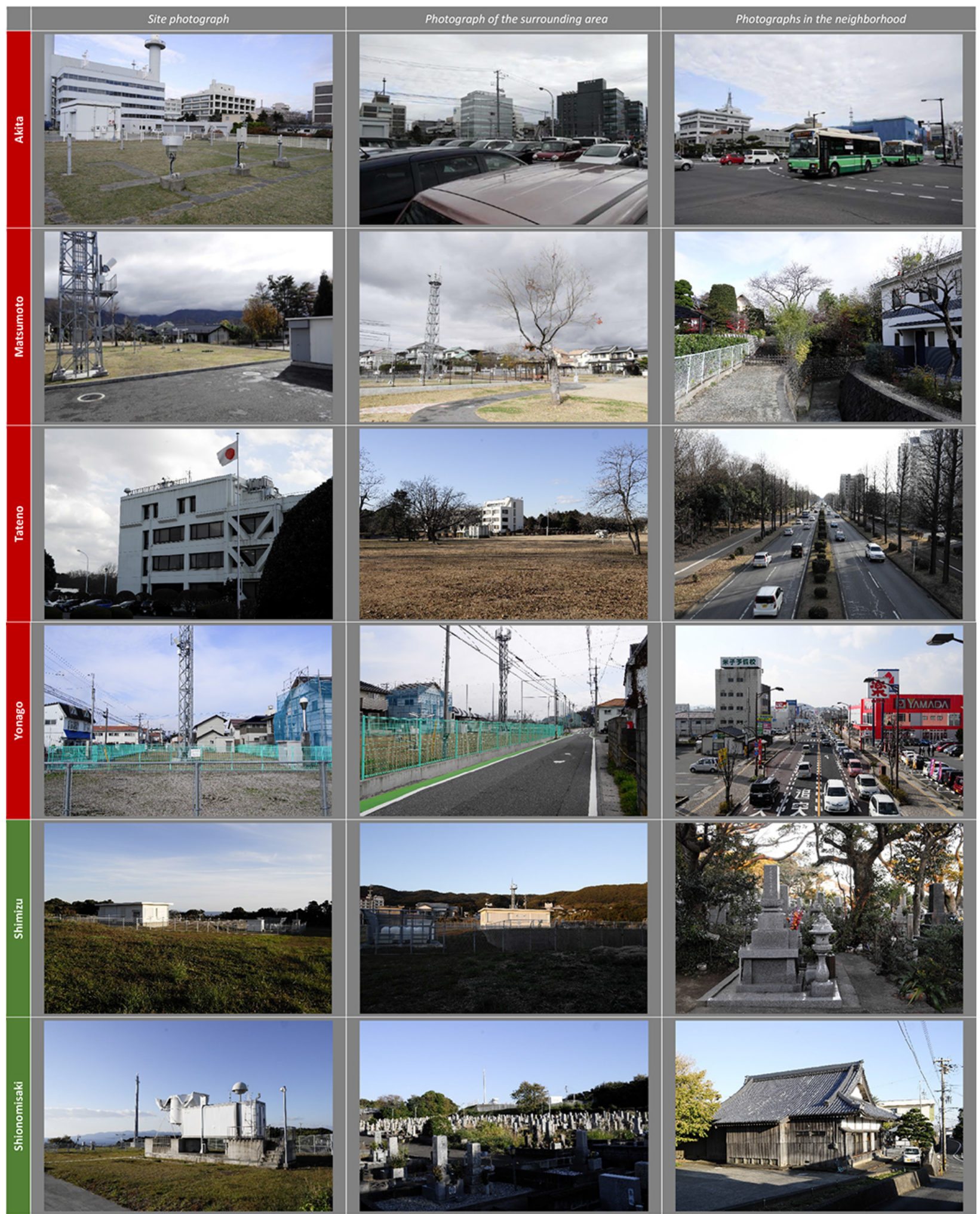

Figure 9. 


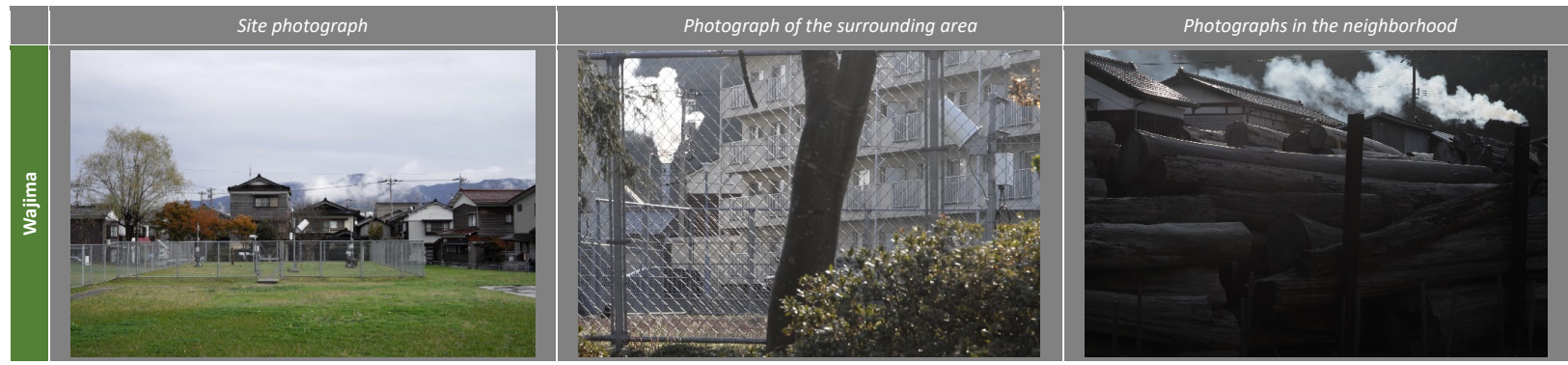

Figure 9. Selected photographs taken during the site visits by K. Tanaka. He paid visit to Akita on 22 November 2015, Matsumoto on 19 November 2015, Tateno on 25 December 2015, Wajima on 20 November 2015 and 28 March 2016, Yonago on 3 January 2016, Shimizu on 29 December 2015, and Shionomisaki on 3 November 2015 and 3 May 2016.
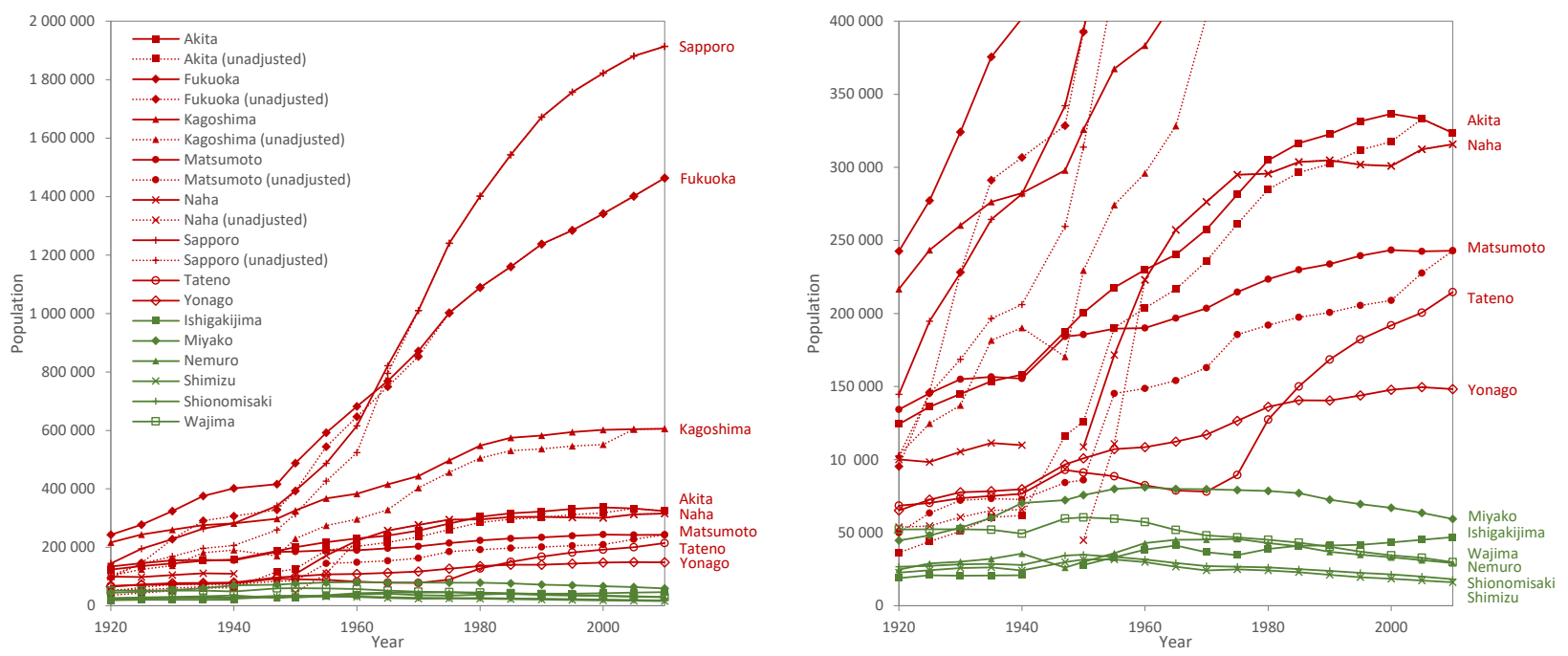

Figure 10. Changes in the census population since 1920 in the municipalities where the 14 Japanese stations are located (in two different vertical scales). Red and green lines indicate polluted and pristine stations, respectively. There have been a number of changes in the municipality boundaries in Japan, particularly during the past 15 years. Population data in solid lines are based on consistent boundaries. In other words, current boundaries are kept all the way back to 1920 to derive population changes. In contrast, population data in dotted lines show those without such corrections after 1980. The nationwide census takes place every 5 years since 1920, with the 1947 census as a replacement with one in 1945 being an exception. There are data gaps in the population data for the Naha and Ishigakijima stations in Okinawa prefecture in 1947 as a result of World War II.

population in Miyako has been decreasing since the 1960s (Fig. 10). The area surrounding Miyako has been unaffected by any city expansion. However, the latest satellite images of Miyako (Fig. 3) do not accurately portray the stable pristine surroundings that have persisted (Figs. 5 and 6 ) because the surrounding area of the site has been heavily affected by the 2011 Tōhoku earthquake and tsunami (Fig. 4). The series of historical maps indicated that there had been no major urban activities in this area prior to the disaster (Figs. 5 and 6).

The Nemuro site has been unchanged since 1886 (Fig. 2). It is located in a remote area at the southeastern edge of Hokkaidō island with no major changes in the surrounding area for a long period of time (Figs. 1, 5, and 6). The population count and density have not significantly changed over the last 100 years (Figs. 10 and 11).
The Shimizu site finds itself in a region known for the untouched nature and detached from industrial activities, except for tourism and fishing. The station is located in one of the least accessible areas in Japan. The Shimizu area is the southernmost point of Shikoku island and has limited road connections, which reflects the geographical and topographical characteristics of the surrounding area (Fig. 3). The area extent and the population of the nearby settlement were stable during the study period (Figs. 6, 10, and 11). The site location has been intact since its founding in 1940 (Fig. 2) and is surrounded by the ocean, residences, and graveyards (Figs. 3 and 9).

The Shionomisaki site is located in a poorly accessible area confined between the Kii Mountains and the Pacific Ocean. The population count and density in Kushimoto, 

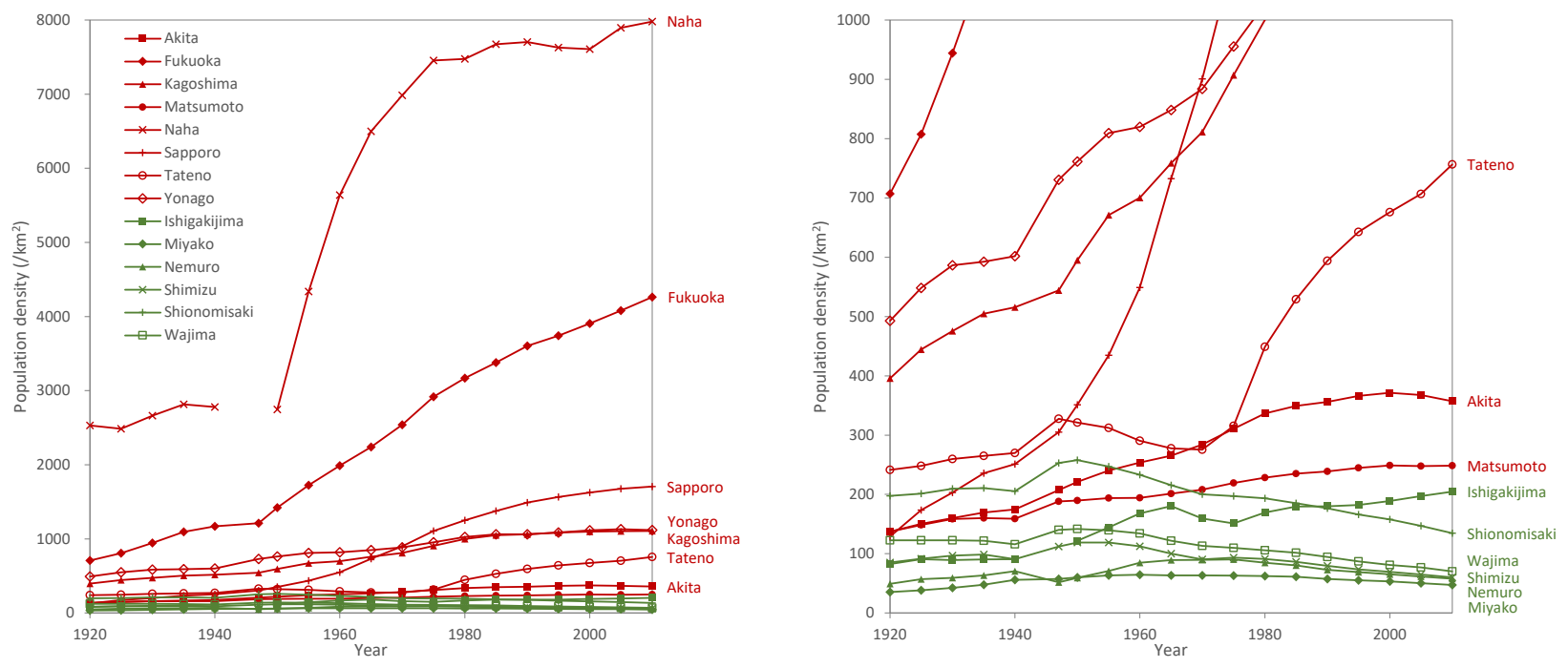

Figure 11. Changes in the population density since 1920 at the municipalities where the 14 Japanese stations are located (in two different vertical scales). See the caption for Fig. 10.

where the site is located, have not substantially changed over the past 100 years, with a small declining trend since 1950s (Figs. 10 and 11). The land use around the site has been mainly residential (Fig. 5). The extent of the built-in area around the site has been almost the same during the study period (Fig. 6). The observatory was inaugurated in 1912 and relocated in 2009 with a distance of approximately $350 \mathrm{~m}$ (Fig. 2). The new site is surrounded by graveyards and residences (Figs. 3 and 9).

The Wajima site is located in a small traditional town culturally known for woodworking and lacquer. The town has not undergone any significant urbanization until present (Figs. 5 and 6). Since 1929 the site has not experienced any relocation of a significant distance (Fig. 2). The population count and density in Wajima are comparable to those in other pristine areas (Figs. 10 and 11). During the site visits by K. Tanaka, however, wood-burning factories were observed just a few hundred meters away from the site today. He witnessed a smokestack in operation during his visits on 20 November 2015 and 28 March 2016 (Fig. 9). Records suggest that the factories have been in operation for the past several decades, leading to speculation that the smokestack might have affected the radiation measurements over a long period of time. Similar to the treatment for Ishigakijima, this site classification is subject to the sensitivity analysis.

With the foregoing station separations based on our best knowledge, we proceed to the SSR and transmittance data analysis in the next section.

\section{SSR and transmittance at the observatories}

\subsection{History of the SSR measurements in Japan}

We begin with a brief historical background of the SSR measurements in Japan. SSR measurements started in 1940 in Sapporo, followed by Nemuro in 1941 and Miyako in 1942, according to the Kishokanpo (in Japanese) report, which consists of the activity records of meteorological stations in Japan, which are disclosed at the Japan Meteorological Agency (JMA). Earliest observations at most of the other sites started in the 1950s. Robitzsch-type pyranometers were used for SSR measurements during this period. In the International Geophysical Year (IGY, July 1957December 1958), more widespread SSR measurements were initiated globally. It was not until 1961 that SSR data became officially available at the JMA website today. During the 1960s, two different types of instrument (i.e., Eppley- and Robitzsch-type pyranometers) (Garg and Garg, 1993) were used in parallel (Fig. 2). Both types of instruments were replaced with Moll-Gorczynski thermopile pyranometers at all sites in the early 1970s, which is when instrumentally harmonized measurements started at the 14 observatories (for an overview of pyranometers and other radiation measurement instruments, see Emeis, 2010). The period that follows saw several station relocations including those for Akita in 1989, Kagoshima in 1994, Miyako in 1990, Naha in 1987, and Shionomisaki in 2009 (Fig. 2). Rather frequent station relocations are not unusual, with the Naha observatory that has been relocated seven times since its inauguration (Fig. 6) being the most extreme case. Since 2007-2010 the radiation measurement campaign has been reduced in scale. This move is partly due to the budget cut, but the reduction in SSR sites is not unrelated to the recent more widespread 


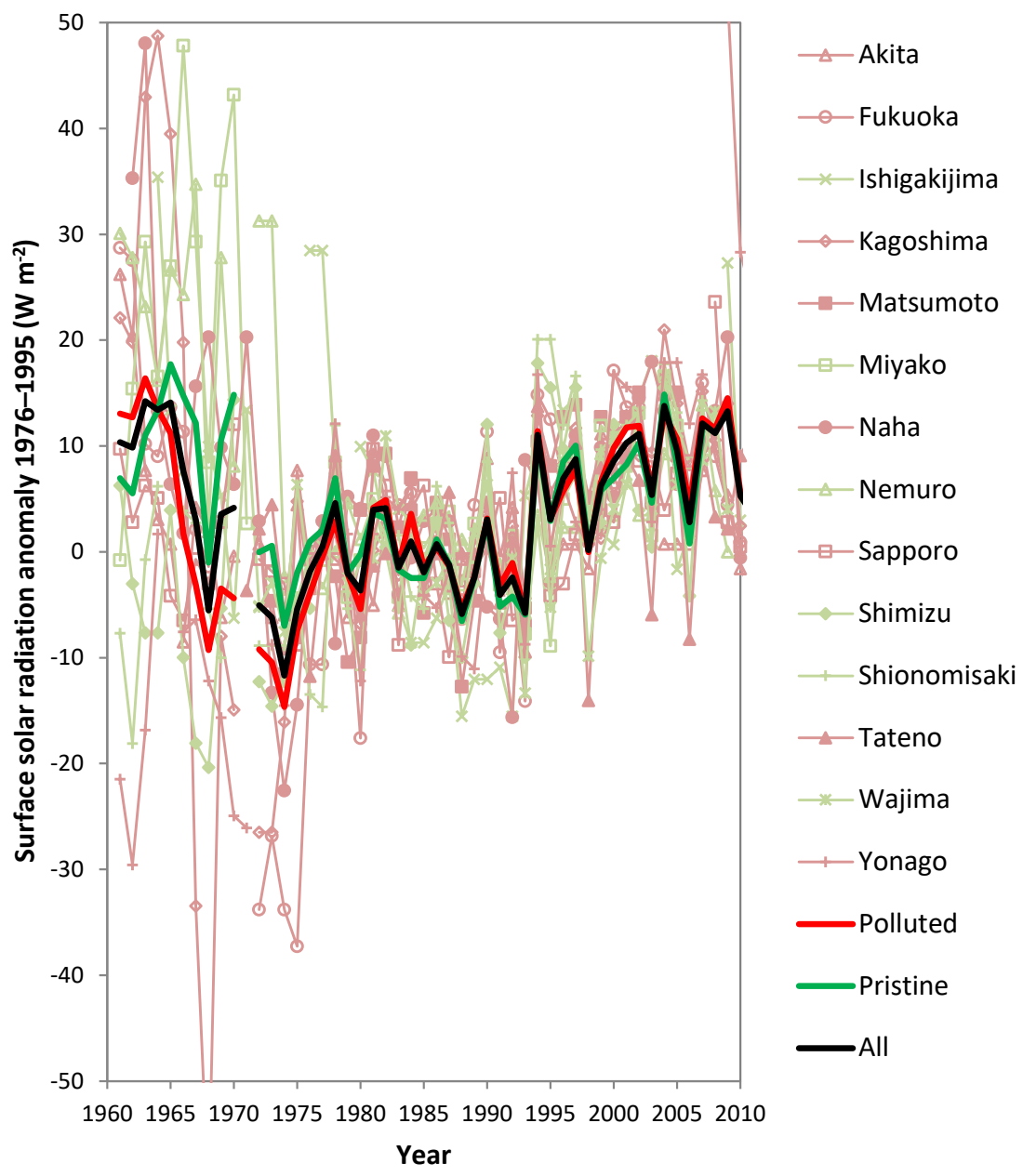

Figure 12. Surface solar radiation anomalies of the 14 Japanese stations used in our analysis. The thick red, green, and black lines are the averages for polluted, pristine, and all stations, respectively. The figure shows the means for SSR and zenith/maximum transmittance data over the polluted, pristine, and all stations only if there are equal to or more than three, three, and six data points, respectively.

use of sunshine duration sites to study global dimming and brightening (Sanchez-Romero et al., 2014). Several observatories including Matsumoto, Miyako, Nemuro, Shimizu, Shionomisaki, Wajima, and Yonago (Fig. 2) have thus been automated. However, automated radiation measurement systems have not been proven reliable over a long period of time. Currently, radiation measurements are not possible without staffs in residence. It is recommended that "pyranometers in continuous operation should be inspected at least once a day and perhaps more frequently, for example when meteorological observations are being made" (World Meteorological Organization, 2014).

\subsection{Data used in our analysis}

SSR data used in our study were collected under the auspices of JMA (http://www.data.jma.go.jp/obd/stats/etrn/ index.php), one of the most concerted and systematic efforts to archive data dating back to as early as the 1870 s (e.g., sur- face temperature and precipitation). The JMA dataset covers more than 100 observatories in Japan and comprises various parameters. We deal with SSR data from 1961 onward, when SSR data are officially available. There are other data in JMA that can be applicable to our study, but our analysis focuses on the confined set of data that we are most familiar with. Note that we do not apply latitudinal corrections for the annual-mean sunshine angle and the effective atmosphere thickness because we inspect the SSR anomalies relative to the 1976-1995 levels, which are unaffected by latitudinal effects.

In addition, we use zenith and maximum transmittance data (calculated from direct solar measurements) to support the analysis to inspect the effect of aerosols on SSR changes. Because the majority of studies indicate that global dimming and brightening in Japan is predominantly caused by aerosols (Kaiser and Qian, 2002; Qian et al., 2006; Norris and Wild, 2009; Kudo et al., 2012), transmittance data, which are more directly related to aerosols because transmission 

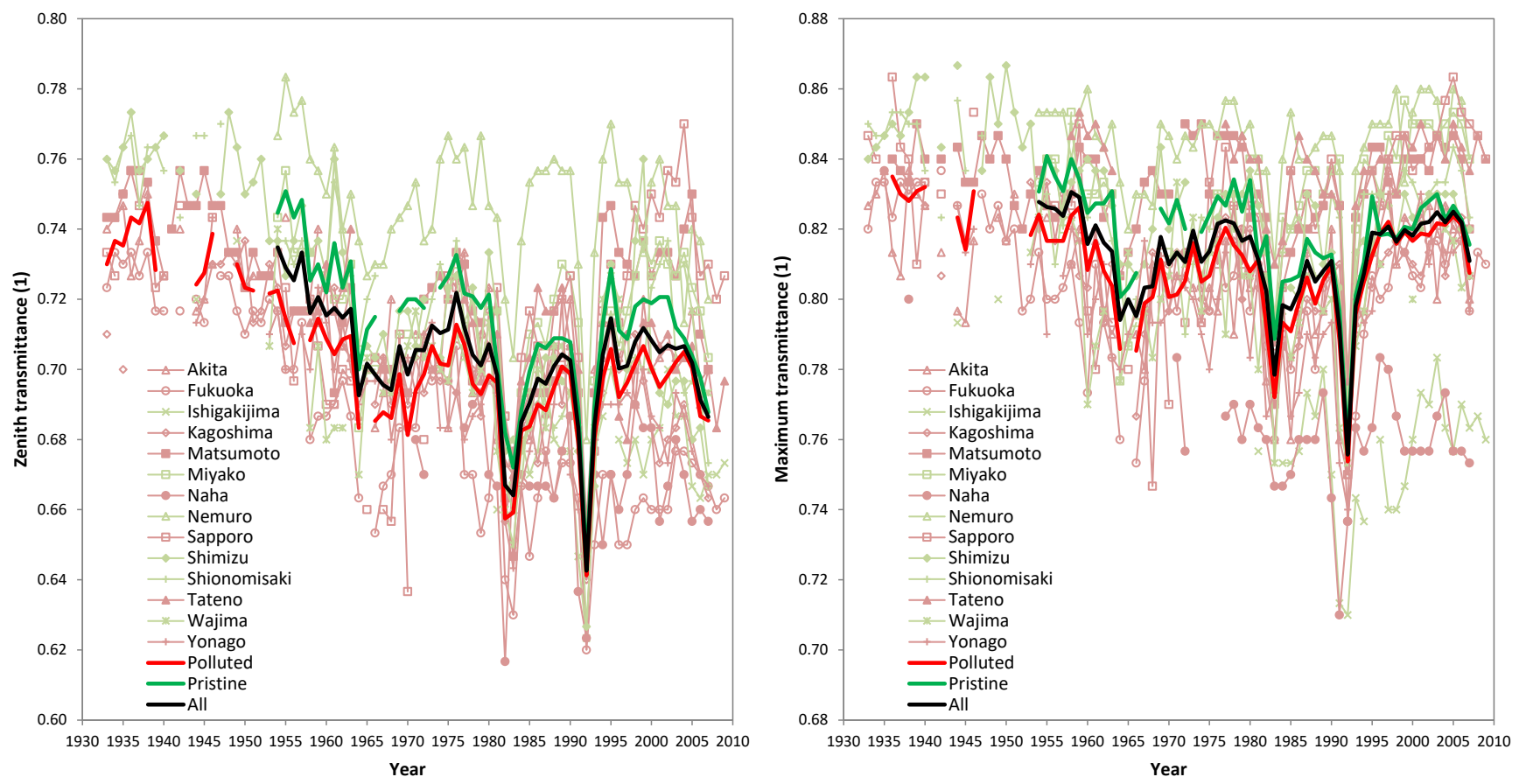

Figure 13. Zenith transmittance and maximum transmittance of the 14 Japanese stations used in our analysis. See the caption for Fig. 12.

measurements are taken only under clear sky conditions, can be insightful. Data for these quantities are available since as early as the 1930s. Mean estimates of the measurements at 09:00, 12:00, and 15:00 LT are used in our analysis. When there are more than 6 months of transmission data available within a year, we take the mean and use it as an annual-mean value. Both of the transmittance quantities were measured by human eyes and are thus subject to human-induced bias. The presence of cirrus clouds, which can be missed without a well-trained observer, can influence the measurements of zenith transmittance. While the measurements of maximum transmittance are free from this problem by definition and are thus believed to have a higher fidelity, this parameter suffers from a representativeness issue since it captures only the extreme in each measurement period. Given the advantages and disadvantages, we look into both zenith and maximum transmittance data in our analysis.

\subsection{SSR trends at the polluted and pristine stations}

All-sky SSR anomaly data averaged over all the stations indicated a dimming until the late 1980s followed by a brightening (Fig. 12), which is consistent with the findings in previous studies (Ohmura, 2009; Skeie et al., 2011; Kudo et al., 2012). The SSR trends averaged over the polluted and pristine sites, which are more important to our analysis, showed no discernible differences. This suggests that local air pollution did not play a role in causing the global dimming and brightening phenomenon in Japan. The same indication was obtained from a few sensitivity cases using different station group compositions (Fig. 15). It is also worth noting the gap in 1971 in SSR data, before which SSR anomalies at individual stations show higher variabilities and larger amplitudes of changes. This is mainly because of the less-accurate instruments used earlier, although this might also be related to the parallel use of two different types of instruments during the 1960s (Fig. 2).

\subsection{Transmittance trends at the polluted and pristine stations}

Further evidence to support the preceding conclusion (i.e., secular SSR changes persisting commonly at polluted and pristine sites) were found in the zenith and maximum transmittance. The zenith and maximum transmittance trends between the polluted and pristine stations followed a similar path and did not diverge over time (Fig. 13). Such an indication is not altered in the sensitivity cases using slightly different station groups (Figs. 16 and 17). This suggests that air pollution does not just locally control the transmittance. In other words, the indication here contradicts the claim that air pollution, owing to continuing urbanization, affects only urban areas.

Measurements from single stations are not in conflict with the abovementioned conclusion although they are subject to larger uncertainties. The zenith and maximum transmittance in Sapporo exhibited steadily upward trends since around 1970 (Fig. 14i). If the change in transmittance were driven by local air pollution, downward trends would instead be anticipated from the urbanization in Sapporo that has been contin- 

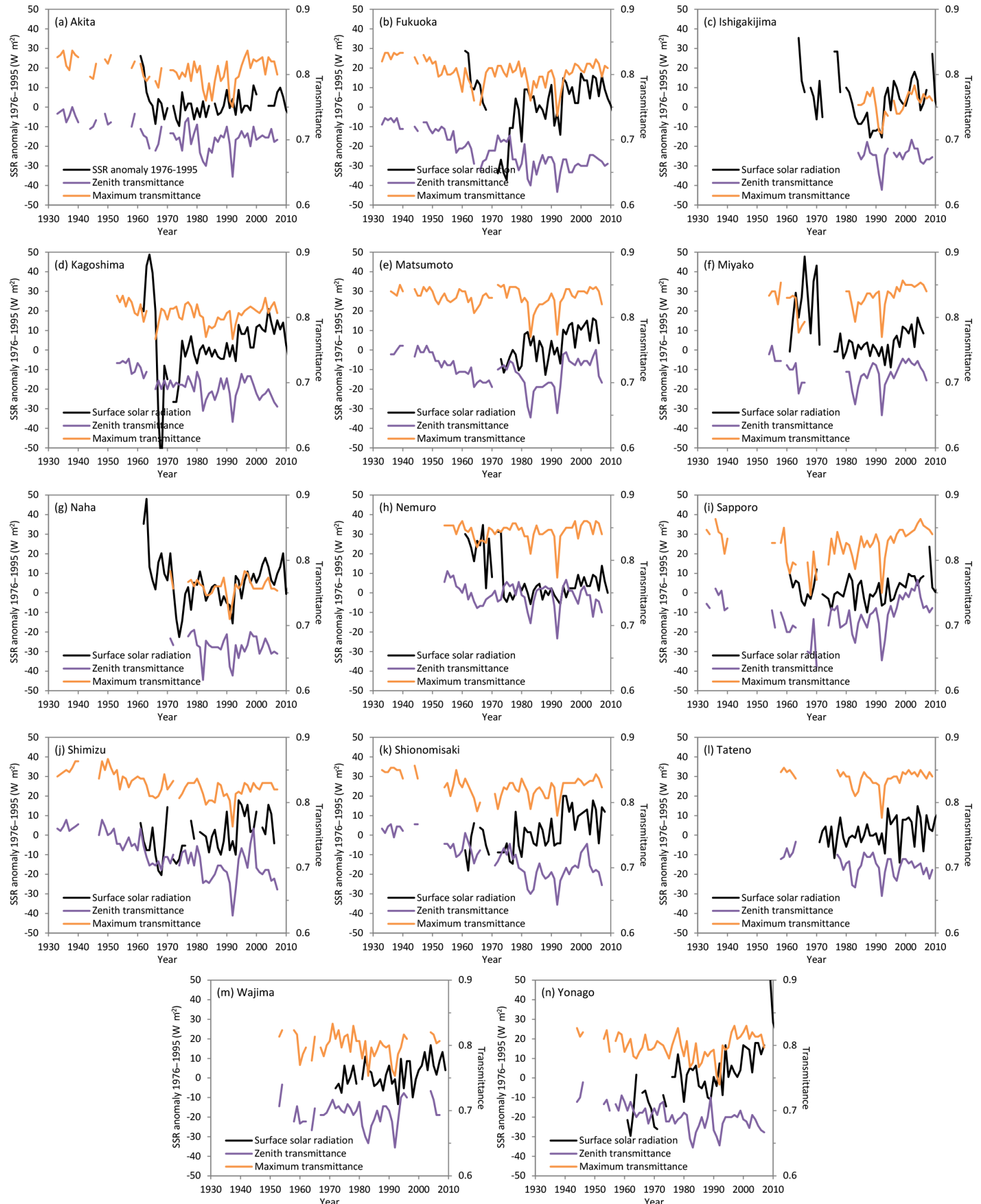

Figure 14. Surface solar radiation anomalies, zenith transmittance, and maximum transmittance measured at individual stations. 

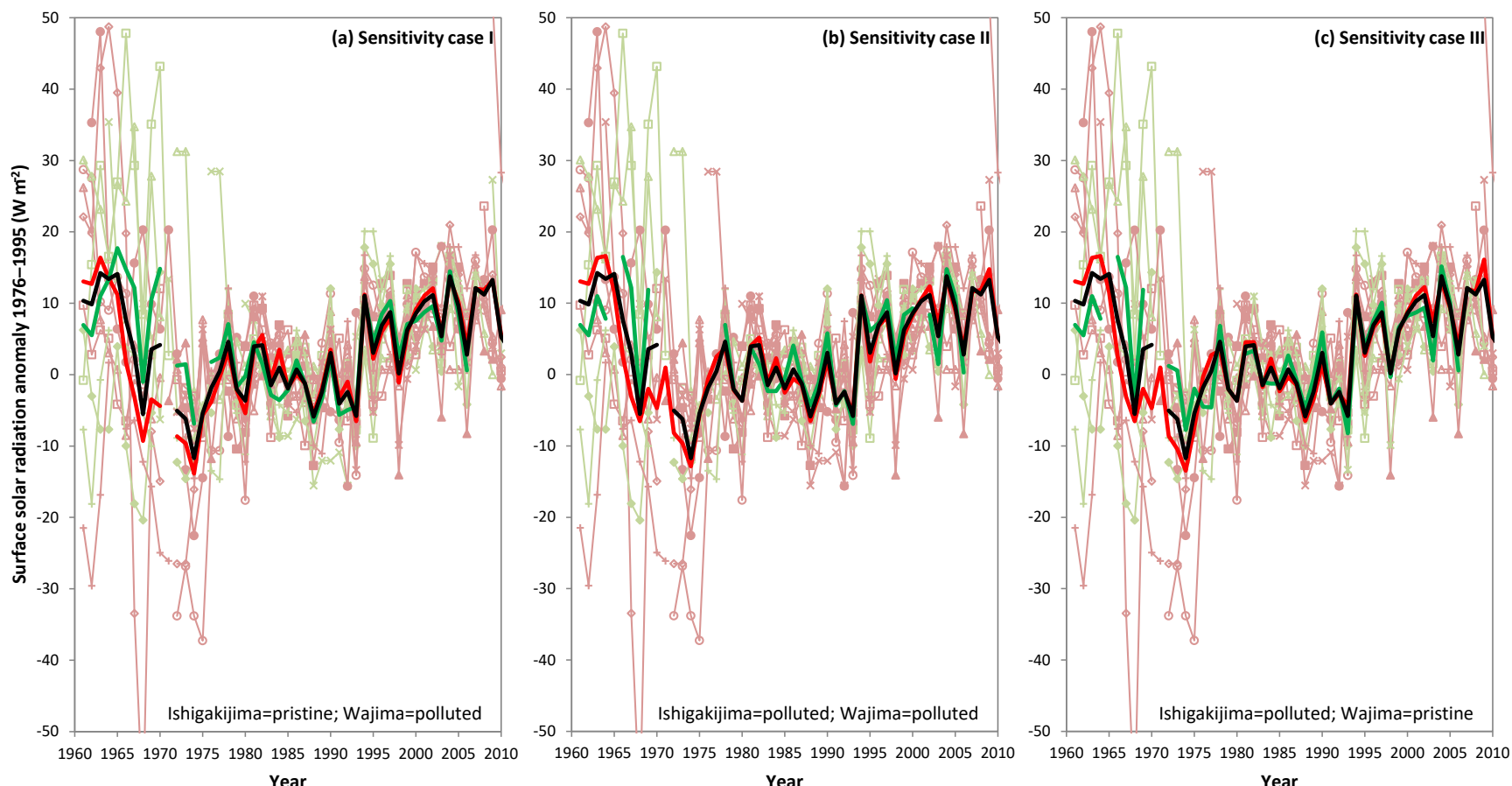

Figure 15. Surface solar radiation anomalies of the 14 Japanese stations categorized into groups in alternative ways. In the sensitivity cases above, the Ishigakijima and Wajima stations, which are in the pristine group in the reference case, are switched to the polluted group one by one (cases I and III) and altogether (case II). See the caption and legend for Fig. 12.
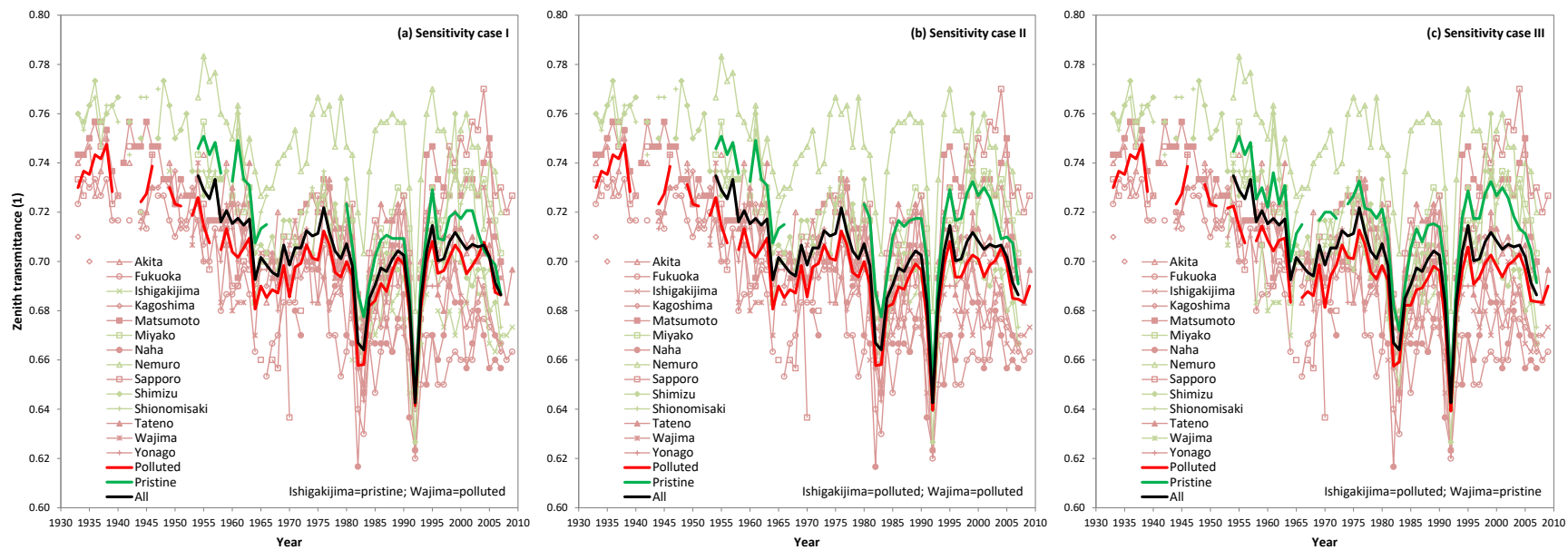

Figure 16. Zenith transmittance of the 14 Japanese stations categorized into groups in alternative ways. See the caption for Fig. 15.

uing until now (Figs. 5, 6, 10, and 11). A contrasting example is the zenith and maximum transmittance levels in Shimizu, both of which have been declining since the 1950s (Fig. 14j). The Shimizu station is known for its persistently clean surroundings since its inauguration, providing no reason locally to support the continuously declining transmittance trends. These findings reinforce the argument that temporal changes in transmittance are not a product of locally confined air pollution.

\subsection{Discussions}

The foregoing data analysis generally indicated that the changes in SSR as well as transmittance are not convincingly explained by local air pollution. Such a conclusion is in line with burgeoning literature on long-range transboundary air pollution (e.g., Ramanathan et al., 2007) and modeling studies indicating long-range transport in the order of hundreds of kilometers (e.g., Folini et al., 2009). Moreover, our general observation is that the majority of studies investigat- 


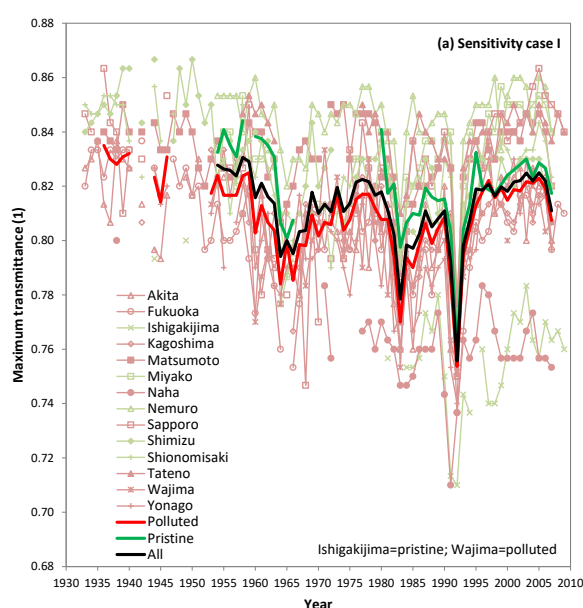

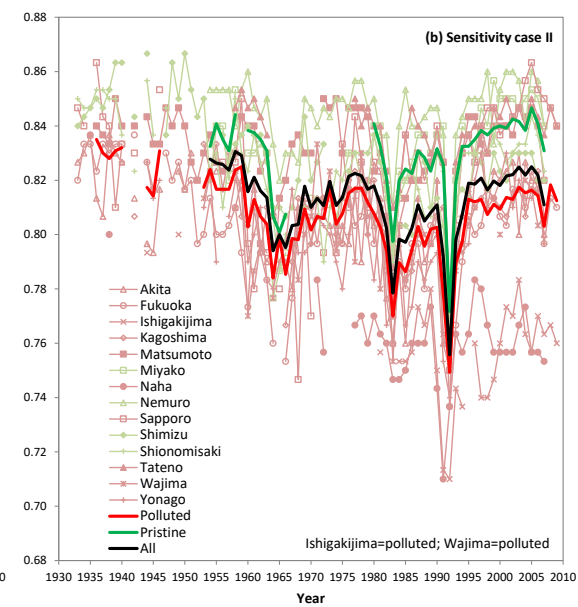

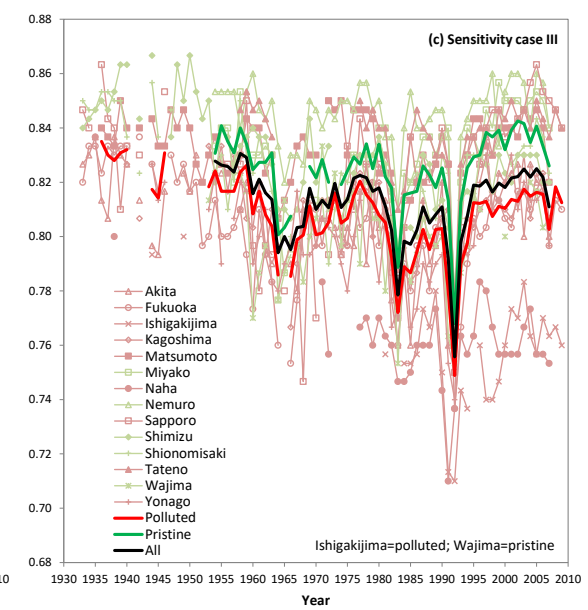

Figure 17. Maximum transmittance of the 14 Japanese stations categorized into groups in alternative ways. See the caption for Fig. 15.

ing SSR trends in different regions of the world converge to similar conclusions. For example, the findings of global dimming and brightening in the Arctic (Stanhill and Callaghan, 1995; Ohmura, 2006) and Antarctica (Stanhill and Cohen, 1997), areas virtually without any human interference, are additional proofs that these variations are not limited to urban regions.

The transmission measurements shown in the present study support the influence of aerosols, as they represent clear sky conditions and show dimming and brightening tendencies, which should not be caused by clouds. This finding supports our premise that global dimming and brightening in Japan is related more to aerosols than clouds, as also indicated by other studies (Kaiser and Qian, 2002; Qian et al., 2006; Norris and Wild, 2009; Kudo et al., 2012). Because the transmittance is not predominantly shaped by local air pollution, global dimming and brightening is not caused by local air pollution but by large scale changes in background aerosols.

Now, a further question arises as to what has determined the overall trend of Japanese transmittance time series. First, the temporal changes in the zenith and maximum transmittance averaged over all the stations are punctuated by the two globally significant discrete events: one related to the El Chichón eruption (Mexico) in 1982 and the other due to the Mount Pinatubo eruption (Philippines) in 1991, as also apparent in the transmittance records at Mauna Loa, Hawaii, USA (Dutton and Bodhaine, 2001). The underlying trend of the all-station transmittance data is generally downward up until 1970s (Fig. 13). We speculate that such a downward trend stems from the urbanization that started earlier (Figs. 7, 10 , and 11), bringing about air pollution, which was not confined locally but rather spread out to larger areas through long-range transport. Then, the transmission trend has leveled off since the 1980s despite continuing urbanization. We hypothesize that two additional competing factors have en- tered around this period: (i) clean air policies that have also started to be implemented in Japan since the 1980s, which contributed to reversing the downward trend, and (ii) longrange transport of air pollution resulting from the rapid development of China starting around the same period, which strengthened the downward trend. The abovementioned argument was inferred from the results of this study, but further research is required to verify the supposition.

\section{Concluding remarks}

We demonstrated multiple lines of evidence suggesting that the global dimming and brightening phenomenon in Japan was not restricted to urban areas and not primarily driven by local air pollution. The evidences include the similar temporal trends of the SSR anomaly and zenith/maximum transmittance data observed at the sets of polluted and pristine stations. Our station classification is based on an extensive collection of data and maps as well as actual station visits. The conclusion is strong against a few sensitivity cases using different station group compositions. Dimming and brightening in Japan is therefore a large-scale phenomenon, independent of local air pollution.

Due to the lack of data to separate aerosol and cloud effects during the historical period, future studies would also need to make use of various types of proxies to understand historical SSR changes. Our approach combining population data, historical land use maps, satellite images, and site visit experiences to infer the pollution level can be applied to regions and countries where such pieces of information are publicly available in sufficient amount and also where stations are easily accessible. Furthermore, studies using highresolution models with a capacity to address more realistic aerosol and cloud representations, including cloud formation over urban area through physical features (Shepherd, 2005; Seto and Shepherd, 2009; Tao et al., 2012), might provide 
a new perspective. Our scientific understanding for this issue will be advanced further when more studies using contrasting approaches are performed and compared to each other.

\section{Data availability}

All the data are available upon request to the authors.

Acknowledgements. K. Tanaka is partially supported by the Marie Curie Intra-European Fellowship within the 7th European Community Framework Programme (Proposal No. 255568 under FP7-PEOPLE-2009-IEF). We thank Adel Imamovic (Swiss Federal Institute of Technology (ETH), Zurich) for contributing to the discussion related to this study. We are grateful for the introduction to measurement activities at Aerological Observatory in Tsukuba provided by Matsumi Takano (Aerological Observatory of Japanese Meteorological Agency). We thank Daisuke Murakami (National Institute for Environmental Studies, Tsukuba) for his technical supports to deal with GIS software packages and georeference the maps. Technical assistance provided by Kazuya Hirota (Atmosphere and Ocean Research Institute, University of Tokyo) to georeference part of the maps used in this study is highly appreciated. Last but not least, we acknowledge the two anonymous referees, whose comments were constructive and useful in refining the paper.

Edited by: T. Takemura

Reviewed by: two anonymous referees

\section{References}

Akimoto, H.: Global Air Quality and Pollution, Science, 302, 17161719, doi:10.1126/science.1092666, 2003.

Allen, R. J., Norris, J. R., and Wild, M.: Evaluation of multidecadal variability in CMIP5 surface solar radiation and inferred underestimation of aerosol direct effects over Europe, China, Japan, and India, J. Geophys. Res.-Atmos., 118, 6311-6336, doi:10.1002/jgrd.50426, 2013.

Alpert, P. and Kishcha, P.: Quantification of the effect of urbanization on solar dimming, Geophys. Res. Lett., 35, L08801, doi:10.1029/2007g1033012, 2008.

Alpert, P., Kishcha, P., Kaufman, Y. J., and Schwarzbard, R.: Global dimming or local dimming?: Effect of urbanization on sunlight availability, Geophys. Res. Lett., 32, L17802, doi:10.1029/2005g1023320, 2005.

Andres, R. J., Boden, T. A., Bréon, F.-M., Ciais, P., Davis, S., Erickson, D., Gregg, J. S., Jacobson, A., Marland, G., Miller, J., Oda, T., Olivier, J. G. J., Raupach, M. R., Rayner, P., and Treanton, K.: A synthesis of carbon dioxide emissions from fossil-fuel combustion, Biogeosciences, 9, 1845-1871, doi:10.5194/bg-9-18452012, 2012.

Dinda, S.: Environmental Kuznets Curve Hypothesis: A Survey, Ecol. Econ., 49, 431-455, doi:10.1016/j.ecolecon.2004.02.011, 2004.

Dutton, E. G. and Bodhaine, B. A.: Solar Irradiance Anomalies Caused by Clear-Sky Transmission Variations above Mauna
Loa: 1958-99, J. Climate, 14, 3255-3262, doi:10.1175/15200442(2001)014<3255:siacbc >2.0.co;2, 2001.

Dwyer, J. G., Norris, J. R., and Ruckstuhl, C.: Do climate models reproduce observed solar dimming and brightening over China and Japan?, J. Geophys. Res.-Atmos., 115, D00K08, doi:10.1029/2009jd012945, 2010.

Emeis, S.: Measurement methods in atmospheric sciences: In situ and remote, Gebrüder Borntraeger, Stuttgart, 2010.

Folini, D. and Wild, M.: Aerosol emissions and dimming/brightening in Europe: Sensitivity studies with ECHAM5-HAM, J. Geophys. Res.-Atmos., 116, D21104, doi:10.1029/2011jd016227, 2011.

Folini, D., Kaufmann, P., Ubl, S., and Henne, S.: Region of influence of 13 remote European measurement sites based on modeled carbon monoxide mixing ratios, J. Geophys. Res.-Atmos., 114, D08307, doi:10.1029/2008jd011125, 2009.

Garg, H. P. and Garg, S. N.: Solar radiation, environment and climate change Measurement of solar radiation - I. Radiation instruments, Renew. Ener., 3, 321-333, doi:10.1016/09601481(93)90099-3, 1993.

Gately, C. K., Hutyra, L. R., and Sue Wing, I.: Cities, traffic, and $\mathrm{CO}_{2}$ : A multidecadal assessment of trends, drivers, and scaling relationships, P. Natl. Acad. Sci. USA, 112, 4999-5004, doi:10.1073/pnas.1421723112, 2015.

Grossman, G. M. and Krueger, A. B.: Economic Growth and the Environment, Q. J. Econ., 110, 353-377, doi:10.2307/2118443, 1995.

Hakuba, M. Z., Folini, D., Sanchez-Lorenzo, A., and Wild, M.: Spatial representativeness of ground-based solar radiation measurements, J. Geophys. Res.-Atmos., 118, 8585-8597, doi:10.1002/jgrd.50673, 2013.

Hayasaka, T., Kawamoto, K., Shi, G., and Ohmura, A.: Importance of aerosols in satellite-derived estimates of surface shortwave irradiance over China, Geophys. Res. Lett., 33, L06802, doi:10.1029/2005GL025093, 2006.

Hofmann, D., Barnes, J., O’Neill, M., Trudeau, M., and Neely, R.: Increase in background stratospheric aerosol observed with lidar at Mauna Loa Observatory and Boulder, Colorado, Geophys. Res. Lett., 36, L15808, doi:10.1029/2009GL039008, 2009.

Holtz-Eakin, D. and Selden, T. M.: Stoking the fires? $\mathrm{CO}_{2}$ emissions and economic growth, J. Public Econ., 57, 85-101, doi:10.3386/w4248, 1995.

Imamovic, A., Tanaka, K., Folini, D., and Wild, M.: Global dimming and urbanization: did stronger negative SSR trends collocate with regions of population growth?, Atmos. Chem. Phys., 16, 2719-2725, doi:10.5194/acp-16-2719-2016, 2016.

Kaiser, D. P. and Qian, Y.: Decreasing trends in sunshine duration over China for 1954-1998: Indication of increased haze pollution?, Geophys. Res. Lett., 29, 2042, doi:10.1029/2002GL016057, 2002.

Kudo, R., Uchiyama, A., Ijima, O., Ohkawara, N., and Ohta, S.: Aerosol impact on the brightening in Japan, J. Geophys. Res.Atmos., 117, D07208, doi:10.1029/2011jd017158, 2012.

Kvalevåg, M. M. and Myhre, G.: Human Impact on Direct and Diffuse Solar Radiation during the Industrial Era, J. Climate, 20, 4874-4883, doi:10.1175/jcli4277.1, 2007.

Lawrence, M. G., Butler, T. M., Steinkamp, J., Gurjar, B. R., and Lelieveld, J.: Regional pollution potentials of megacities and 
other major population centers, Atmos. Chem. Phys., 7, 39693987, doi:10.5194/acp-7-3969-2007, 2007.

Liepert, B., Fabian, P., and Grassl, H.: Solar radiation in Germany - Observed trends and an assessment of their causes. Part 1: Regional approach, Beitragen Atmosphärenphysik, 67, 15-29, 1994.

Liepert, B. G.: Observed reductions of surface solar radiation at sites in the United States and worldwide from 1961 to 1990, Geophys. Res. Lett., 29, 1421, doi:10.1029/2002GL014910, 2002.

Liley, J. B.: New Zealand dimming and brightening, J. Geophys. Res.-Atmos., 114, D00D10, doi:10.1029/2008JD011401, 2009.

Lin, J., Pan, D., Davis, S. J., Zhang, Q., He, K., Wang, C., Streets, D. G., Wuebbles, D. J., and Guan, D.: China's international trade and air pollution in the United States, P. Natl. Acad. Sci. USA, 111, 1736-1741, doi:10.1073/pnas.1312860111, 2014.

McConnell, J. R., Edwards, R., Kok, G. L., Flanner, M. G., Zender, C. S., Saltzman, E. S., Banta, J. R., Pasteris, D. R., Carter, M. M., and Kahl, J. D. W.: 20th-Century Industrial Black Carbon Emissions Altered Arctic Climate Forcing, Science, 317, 13811384, doi:10.1126/science.1144856, 2007.

Monks, P. S., Granier, C., Fuzzi, S., Stohl, A., Williams, M. L., Akimoto, H., Amann, M., Baklanov, A., Baltensperger, U., Bey, I., Blake, N., Blake, R. S., Carslaw, K., Cooper, O. R., Dentener, F., Fowler, D., Fragkou, E., Frost, G. J., Generoso, S., Ginoux, P., Grewe, V., Guenther, A., Hansson, H. C., Henne, S., Hjorth, J., Hofzumahaus, A., Huntrieser, H., Isaksen, I. S. A., Jenkin, M. E., Kaiser, J., Kanakidou, M., Klimont, Z., Kulmala, M., Laj, P., Lawrence, M. G., Lee, J. D., Liousse, C., Maione, M., McFiggans, G., Metzger, A., Mieville, A., Moussiopoulos, N., Orlando, J. J., O’Dowd, C. D., Palmer, P. I., Parrish, D. D., Petzold, A., Platt, U., Pöschl, U., Prévôt, A. S. H., Reeves, C. E., Reimann, S., Rudich, Y., Sellegri, K., Steinbrecher, R., Simpson, D., ten Brink, H., Theloke, J., van der Werf, G. R., Vautard, R., Vestreng, V., Vlachokostas, C., and von Glasow, R.: Atmospheric composition change - global and regional air quality, Atmos. Environ., 43, 5268-5350, doi:10.1016/j.atmosenv.2009.08.021, 2009.

Norris, J. R. and Wild, M.: Trends in aerosol radiative effects over Europe inferred from observed cloud cover, solar "dimming", and solar "brightening", J. Geophys. Res.-Atmos., 112, D08214, doi:10.1029/2006JD007794, 2007.

Norris, J. R. and Wild, M.: Trends in aerosol radiative effects over China and Japan inferred from observed cloud cover, solar "dimming", and solar "brightening", J. Geophys. Res.-Atmos., 114, D00D15, doi:10.1029/2008jd011378, 2009.

Ohmura, A.: Observed Long-Term Variations of Solar Irradiance at the Earth's Surface, Space Sci. Rev., 125, 111-128, doi:10.1007/s11214-006-9050-9, 2006.

Ohmura, A.: Observed decadal variations in surface solar radiation and their causes, J. Geophys. Res., 114, D00D05, doi:10.1029/2008jd011290, 2009.

Ohmura, A.: The Development and the Present Status of Energy Balance Climatology, J. Meteorol. Soc. Jpn. II, 92, 245-285, doi:10.2151/jmsj.2014-401, 2014.

Ohmura, A. and Lang, H.: Secular variation of global radiation over Europe, in: Current Problems in Atmospheric Radiation, edited by: Lenoble, J., Geleyn, J. F., and Deepak, A., Hampton, 1989.

Pinker, R. T., Zhang, B., and Dutton, E. G.: Do Satellites Detect Trends in Surface Solar Radiation?, Science, 308, 850-854, doi:10.1126/science.1103159, 2005.
Qian, Y., Kaiser, D. P., Leung, L. R., and Xu, M.: More frequent cloud-free sky and less surface solar radiation in China from 1955 to 2000, Geophys. Res. Lett., 33, L01812, doi:10.1029/2005GL024586, 2006.

Ramanathan, V., Li, F., Ramana, M. V., Praveen, P. S., Kim, D., Corrigan, C. E., Nguyen, H., Stone, E. A., Schauer, J. J., Carmichael, G. R., Adhikary, B., and Yoon, S. C.: Atmospheric brown clouds: Hemispherical and regional variations in long-range transport, absorption, and radiative forcing, J. Geophys. Res.-Atmos., 112, D22S21, doi:10.1029/2006jd008124, 2007.

Ruckstuhl, C. and Norris, J. R.: How do aerosol histories affect solar "dimming" and "brightening" over Europe?: IPCC-AR4 models versus observations, J. Geophys. Res.-Atmos., 114, D00D04, doi:10.1029/2008JD011066, 2009.

Ruckstuhl, C., Philipona, R., Behrens, K., Collaud Coen, M., Dürr, B., Heimo, A., Mätzler, C., Nyeki, S., Ohmura, A., Vuilleumier, L., Weller, M., Wehrli, C., and Zelenka, A.: Aerosol and cloud effects on solar brightening and the recent rapid warming, Geophys. Res. Lett., 35, L12708, doi:10.1029/2008g1034228, 2008.

Russak, V.: Changes in solar radiation and their influence on temperature trend in Estonia (1955-2007), J. Geophys. Res.-Atmos., 114, D00D01, doi:10.1029/2008JD010613, 2009.

Sanchez-Lorenzo, A. and Wild, M.: Decadal variations in estimated surface solar radiation over Switzerland since the late 19th century, Atmos. Chem. Phys., 12, 8635-8644, doi:10.5194/acp-128635-2012, 2012.

Sanchez-Romero, A., Sanchez-Lorenzo, A., Calbó, J., González, J. A., and Azorin-Molina, C.: The signal of aerosolinduced changes in sunshine duration records: A review of the evidence, J. Geophys. Res.-Atmos., 119, 4657-4673, doi:10.1002/2013JD021393, 2014.

Sangyochiiki_Kenkyusho: Zenkokutoshi no sasutenaburudo hyouka, Nihonkeizai Shinbunsha, 2012 (in Japanese).

Seto, K. C. and Shepherd, J. M.: Global urban land-use trends and climate impacts, Current Opinion in Environmental Sustainability, 1, 89-95, doi:10.1016/j.cosust.2009.07.012, 2009.

Shepherd, J. M.: A Review of Current Investigations of UrbanInduced Rainfall and Recommendations for the Future, Earth Interact., 9, 1-27, doi:10.1175/ei156.1, 2005.

Skeie, R. B., Berntsen, T. K., Myhre, G., Tanaka, K., Kvalevåg, M. M., and Hoyle, C. R.: Anthropogenic radiative forcing time series from pre-industrial times until 2010, Atmos. Chem. Phys., 11, 11827-11857, doi:10.5194/acp-11-11827-2011, 2011.

Solomon, S., Daniel, J. S., Neely, R. R., Vernier, J.-P., Dutton, E. G., and Thomason, L. W.: The Persistently Variable "Background" Stratospheric Aerosol Layer and Global Climate Change, Science, 333, 866-870, doi:10.1126/science.1206027, 2011.

Stanhill, G. and Callaghan, T. V.: Solar Irradiance, Air Pollution and Temperature Changes in the Arctic, Philos. T. R. Soc. Lond. A, 352, 247-258, doi:10.1098/rsta.1995.0068, 1995.

Stanhill, G. and Cohen, S.: Recent Changes in Solar Irradiance in Antarctica, J. Climate, 10, 2078-2086, doi:10.1175/15200442(1997)010<2078:RCISII>2.0.CO;2, 1997.

Stanhill, G. and Cohen, S.: Global dimming: a review of the evidence for a widespread and significant reduction in global radiation with discussion of its probable causes and possible agricultural consequences, Agr. Forest Meteorol., 107, 255-278, doi:10.1016/S0168-1923(00)00241-0, 2001. 
Stanhill, G. and Cohen, S.: Is solar dimming global or urban? Evidence from measurements in Israel between 1954 and 2007, J. Geophys. Res.-Atmos., 114, D00D17, doi:10.1029/2009jd011976, 2009.

Stanhill, G. and Moreshet, S.: Global radiation climate changes: The world network, Climatic Change, 21, 57-75, doi:10.1007/bf00143253, 1992.

Streets, D. G., Wu, Y., and Chin, M.: Two-decadal aerosol trends as a likely explanation of the global dimming/brightening transition, Geophys. Res. Lett., 33, L15806, doi:10.1029/2006g1026471, 2006.

Tang, W.-J., Yang, K., Qin, J., Cheng, C. C. K., and He, J.: Solar radiation trend across China in recent decades: a revisit with quality-controlled data, Atmos. Chem. Phys., 11, 393-406, doi:10.5194/acp-11-393-2011, 2011.

Tao, W.-K., Chen, J.-P., Li, Z., Wang, C., and Zhang, C.: Impact of aerosols on convective clouds and precipitation, Rev. Geophys., 50, 2011RG000369, doi:10.1029/2011RG000369, 2012.

Tsutsumi, Y. and Murakami, S.: Increase in Global Solar Radiation with Total Cloud Amount from 33 Years Observations in Japan, J. Meteorol. Soc. Jpn. II, 90, 575-581, doi:10.2151/jmsj.2012409, 2012.

Wang, K.: Measurement Biases Explain Discrepancies between the Observed and Simulated Decadal Variability of Surface Incident Solar Radiation, Scientific Reports, 4, 6144, doi:10.1038/srep06144, 2014.

Wang, K., Ma, Q., Wang, X., and Wild, M.: Urban impacts on mean and trend of surface incident solar radiation, Geophys. Res. Lett., 41, 4664-4668, doi:10.1002/2014GL060201, 2014.

Wang, K. C., Dickinson, R. E., Wild, M., and Liang, S.: Atmospheric impacts on climatic variability of surface incident solar radiation, Atmos. Chem. Phys., 12, 9581-9592, doi:10.5194/acp12-9581-2012, 2012

Wang, Y. W. and Yang, Y. H.: China's dimming and brightening: evidence, causes and hydrological implications, Ann. Geophys., 32, 41-55, doi:10.5194/angeo-32-41-2014, 2014.

Wild, M.: Global dimming and brightening: A review, J. Geophys. Res., 114, D00D16, doi:10.1029/2008jd011470, 2009.
Wild, M.: Enlightening Global Dimming and Brightening, B. Am. Meteorol. Soc., 93, 27-37, doi:10.1175/bams-d-11-00074.1, 2012.

Wild, M. and Schmucki, E.: Assessment of global dimming and brightening in IPCC-AR4/CMIP3 models and ERA40, Clim. Dynam., 37, 1671-1688, doi:10.1007/s00382-010-0939-3, 2011.

Wild, M., Gilgen, H., Roesch, A., Ohmura, A., Long, C. N., Dutton, E. G., Forgan, B., Kallis, A., Russak, V., and Tsvetkov, A.: From Dimming to Brightening: Decadal Changes in Solar Radiation at Earth's Surface, Science, 308, 847-850, doi:10.1126/science.1103215, 2005.

World_Meteorological_Organization: Provisional 2014 Edition of the Guide to Meteorological Instruments and Methods of Observation, World_Meteorological_Organization, 2014.

You, Q., Sanchez-Lorenzo, A., Wild, M., Folini, D., Fraedrich, K., Ren, G., and Kang, S.: Decadal variation of surface solar radiation in the Tibetan Plateau from observations, reanalysis and model simulations, Clim. Dynam., 40, 2073-2086, doi:10.1007/s00382-012-1383-3, 2013.

Yu, H., Remer, L. A., Chin, M., Bian, H., Kleidman, R. G., and Diehl, T.: A satellite-based assessment of transpacific transport of pollution aerosol, J. Geophys. Res.-Atmos., 113, D14S12, doi:10.1029/2007JD009349, 2008.

Yu, H., Remer, L. A., Chin, M., Bian, H., Tan, Q., Yuan, T., and Zhang, Y.: Aerosols from Overseas Rival Domestic Emissions over North America, Science, 337, 566-569, doi:10.1126/science.1217576, 2012.

Yu, H., Chin, M., West, J. J., Atherton, C. S., Bellouin, N., Bergmann, D., Bey, I., Bian, H., Diehl, T., Forberth, G., Hess, P., Schulz, M., Shindell, D., Takemura, T., and Tan, Q.: A multimodel assessment of the influence of regional anthropogenic emission reductions on aerosol direct radiative forcing and the role of intercontinental transport, J. Geophys. Res.-Atmos., 118, 700-720, doi:10.1029/2012JD018148, 2013. 